

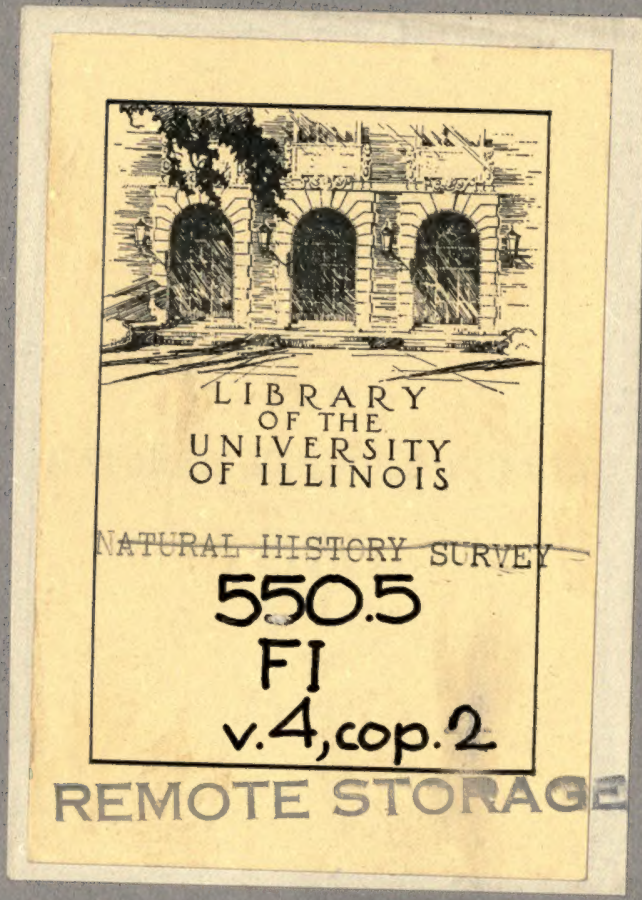






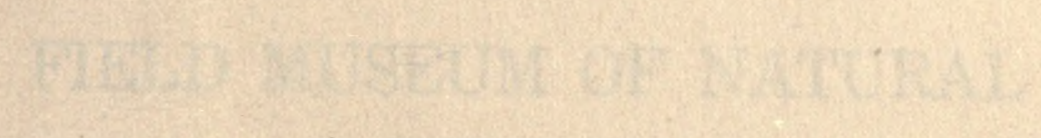

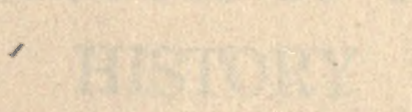

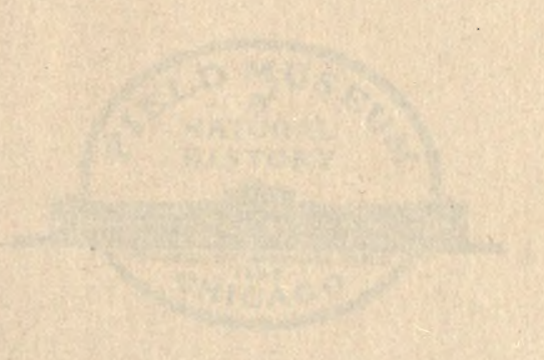


LIBRARY

UNIVERSIIY OF ILLINOIS

URBANA 
Field Museum of Natural History.

Publication i 71 .

Geological Series.

Vol. IV, No. 3 .

\section{NEW TRILOBITES FROM THE MAQUOKETA BEDS OF FAYETTE COUNTY, IOWA}

By

Arthur Ware Slocom, Assistant Curator, Section of Invertebrate Paleontology.

Oliver Cummings Farrington; Curator, Department of Geology.

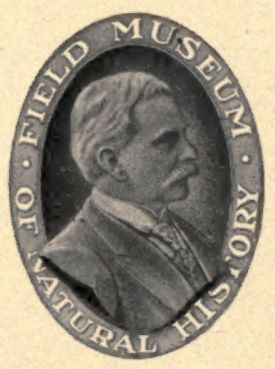

Chicago, U. S. A. October, I9I3. 



\section{NEW TRILOBITES FROM THE MAQUOKETA BEDS OF FAYETTE COUNTY, IOWA}

\section{BY ARTHUR WARE SLOCOM}

The specimens upon which this paper is based represent the results of two visits to Fayette County, Iowa, made by the writer, one in July, I9I0, and the other in October, I9I2, supplemented by specimens from the collection of Mr. A. G. Becker of Clermont, Iowa, and from the collections of the State University of Iowa.

The Maquoketa beds constitute the uppermost deposits of the Ordovician system found in the state of Iowa. In a few localities they are overlaid, unconformably, by Niagaran limestones, but usually they underlie the drift. These beds have been worked out by Savage in his "Geology of Fayette County." * He divides the formation into Lower, Middle and Upper Maquoketa beds. The Lower member attains a maximum thickness of 95 feet and consists of alternating layers of shale and argillaceous limestone. Some of the layers are quite fossiliferous. The Middle division consists of 40 to 60 feet of cherty limestone with few fossils. No trilobites have been observed from these beds. The Upper division has a thickness in some places of I 25 feet. It is composed of a plastic blue-gray shale. In the upper portion occurs a zone 8 to 12 feet in thickness, in which are thin calcareous layers composed almost entirely of fossil shells. Below this zone the shale is practically barren of fossils, but contains numerous crystals of selenite. The lithological characters of the various divisions of the Maquoketa beds are quite constant at the various exposures studied.

The Maquoketa beds of Fayette County afford a fauna of unusual interest both as to the number of species represented and the excellent state of preservation of the specimens. Other localities afford a greater number of individuals, but few, if any, excel it in the quality of the material. Savage $\dagger$ reports 68 species divided as follows: Sponges 2, Corals 2, Brachiopods 3I, Pelecypods 4, Gastropods I I, Pteropods 2, Cephalopods 7 , and Trilobites 9 .

In the material collected and identified by the writer, the number of species obtained in the various groups agrees practically with the above list with the exception of the trilobites. Of these twenty species

*Iowa Geological Survey, I904, Vol. XV, pp. 433-546.

†Loc. cit., p. $4^{86}$. 


\section{Field Museum of Natural History-Geology, Vol. IV.}

were determined. A number of species of crinoids and cystoids, probably six or eight species of which Savage made no mention, were also found. Of the twenty species of trilobites twelve were found to be new and are here described and figured. Five of the eight species which have been previously described are here redescribed and figured. The remaining three species were too fragmentary to admit of description.

Thus far the only group that has been critically studied by the writer is the trilobites and the finding of so many new species in that group would indicate that when the other groups are studied new material will be discovered. A beginning has been made on the echinoderms, and so far none of them appears to be referable to known species. If they prove to be new, they will probably be described in a future paper.

\section{CLASSIFICATION AND TERMINOLOGY}

The classification here used is that prepared by Prof. Charles E. Beecher and given in the English edition of Zittel's Text Book of Paleon-

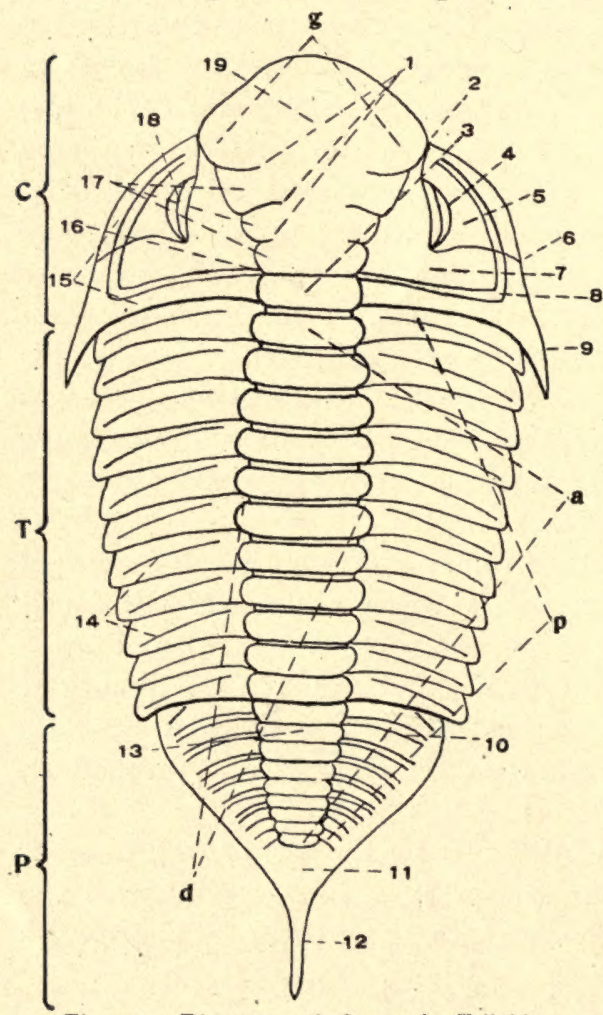

Figure $x$. Diagrammatic figure of a Trilobite. tology. For definitions of the various orders and families the reader is referred to that work.

In order to make clear in what sense various terms are used by the writer, the following glossary is given. The letters or figures in parentheses refer to text figure $\mathrm{I}$.

Annulations: The ring-like divisions of the axis of the pygidium. (I3)

Anterior: Situated in front.

Anterior limb of the facial suture: The portion of the facial suture lying in front of the eye. (2)

Axis: The median longitudinal lobe of a trilobite. (a).

Carapace: The hard shell covering the dorsal surface of a trilobite.

Caudal spine: A spine at the posterior extremity of the pygidium. (I 2 ) 
Cephalon: The head of a trilobite. (C)

Cheeks: The two lateral portions of the head or cephalon of a trilobite, divided into fixed (7) and free (5) cheeks by a facial suture.

Compound eyes: Eyes commonly present upon the free cheeks of trilobites; they are made up of a large number of small facets. (4)

Cranidium: The portion of the head or cephalon of a trilobite lying between the facial sutures, comprising the glabella and the fixed cheeks.

Distal: Away from the median line.

Dorsal: Pertaining to the back.

Dorsal furrows: The furrows or depressions bounding the axial or medial longitudinal lobe of a trilobite; same as the axial furrows.

Doublure: The infolded margin of the trilobite test.

Facial suture: The suture in the head or cephalon of a trilobite separating the fixed from the free cheeks. $(2,6)$

Fixed cheek: The portion of the cephalon or head of a trilobite lying between the glabella and the facial suture.

Free cheek: Lateral portion of the cephalon or head of a trilobite, lying between the facial suture and the lateral cephalic border.

Frontal lobe: That portion of the glabella anterior to the first lateral furrows. (I9)

Genal angles: The postero-lateral angles of the cephalon or head of a trilobite.

Genal spines: The posterior prolongation into spines of the genal angles of a trilobite.

Glabella: The central or axial portion of the cephalon or head of a trilobite.

Holochroal eyes: Compound eyes of a trilobite whose visual area is covered with a continuous horny integument.

Hypostoma: The under lip of a trilobite.

Lateral furrows: The transverse furrows or grooves of the trilobite glabella, sometimes continuous across the glabella and sometimes greatly modified. (I) These furrows define the lobes of the glabella. (I 7$)$

Marginal border: The thickened or otherwise differentiated external border of the cephalon and pygidium of a trilobite. (I5)

Marginal furrow: The groove or depression lying just within the marginal border of the cephalon and pygidium of a trilobite.

Occipital furrow: The posterior transverse groove or furrow of the glabella of a trilobite, lying in front of the occipital segment.

Occipital lobes: Small, lateral lobes of the occipital segment present in some trilobites, which are morphologically different from the lateral lobe of the glabella. 
46 Field Museum of Natural History - Geology, Vol. IV.

Occipital or neck segment: The posterior transverse segment of the trilobite glabella, lying between the posterior margin and the occipital furrow. (3)

Ocular ridges: Ridges extending from near the anterior extremity of the glabella to the eyes in some trilobites. The eye lines.

Palpebral lobes: Lobes of the fixed cheeks within the margins of the eyes. The eye lobes. (I 8 )

Pleura: The two lateral longitudinal lobes of a trilobite, applied chiefly to the thoracic region and the pygidium.

Pleural grooves: Grooves on the pleuræ of the thoracic segments. (I4)

Pleural ribs: The fused segments in the lateral lobes of the pygidium. (Io)

Post-axial region: The flattened area occupying the median portion of the pygidium of some trilobites, posterior to the elevated axis. (I I)

Post-cephalic margin: The posterior margin of the head or cephalon.

Posterior cheek furrow: The marginal furrows or grooves present in some trilobites, which extend across the cheeks from the extremities of the occipital furrow of the glabella towards the genal angles.

Posterior limb of facial suture: That portion of the facial suture extending from the posterior extremity of the eye to the posterior or lateral margin of the cephalon. (6)

Proximal: Toward the median line.

Punctate: Having minute depressions or pits.

Pustulose: Covered with pustules or blister-like prominences.

Pygidium: The tail or posterior region of the trilobite test.

Schizochroal eyes: Compound eyes of the trilobites in which the visual area is occupied by small openings for the separate facets.

Segments: The transverse divisions of the thorax or pygidium.

Test: The hard outer covering of the trilobite.

Thorax: The central segmented region of the body of trilobites. (T)

Ventral: Pertaining to the under surface. 
DESCRIPTION OF GENERA AND SPECIES.

\section{Order OPISTHOPARIA. \\ Family ASAPHID E, Emmrich}

Genus ISOTELUS DeKay 1824 .

Cephalic and caudal shields of nearly equal size with broad infolded margins; glabella nearly smooth, not lobed; free cheeks large, sometimes meeting in front of the cranidium; eves prominent holochroal; hypostoma deeply forked; thoracic axis wide; pygidium obscurely lobed, segmentation often obsolete at maturity. This genus is distinguished from Asaphus by the absence of the lobation of the glabella, the distinct segmentation of the pygidial axis and the wider thoracic axis.

\section{ISOTELUS Gigas DeKay.}

I. gigas DeKay, r824. Ann. Lyceum Nat. Hist. N. Y., Vol. I, p. I 74, pl. I2, fig. I, pl. I3, fig. I.

I. gigas Clarke, I897. Pal. Minn. Vol. III, pt. 2, p. 70 I and 706.

A portion of a pygidium from the Lower Maquoketa at Clermont and one from the Upper Maquoketa at Patterson's Springs, on account of their size are doubtfully referred to this species. These are the representation of this species from Fayette County in the Museum collection. The State University of Iowa has in its collection a nearly complete individual of this species from the Maquoketa of Florenceville, Howard Co., Iowa, so that the species may be looked for in Fayette County.

IsoTELUS MAXIMUS Locke.

I. maximus Locke, 1838. Sec. Ann. Rept., Geol. Surv., Ohio, p. 246, figs. 8, 9 .

I. megistos Locke, I84I. Trans. Am. Geol. and Nat., p. 22 I.

I. maximus Clarke, I897. Pal. Minn. Vol. III, pt. 2, p. 70 I and 706.

This species is represented in the Museum collections by one cephalon in which the specific characters are well shown and several pygidia which probably belong to the species. They were found near the top of the Lower Maquoketa beds at Clermont. Most of the specimens of Isotelus from this locality which have been referred by other authors to $I$. maximus are here referred to $I$. inwensis Owen. (See remarks under that species.) 
Isotelus Iowensis Owen. Plate XIII, figs. I-2.

I. iowensis Owen, I852. Rept. Geol. Surv. Wis., Ia. and Minn., p. $577, \mathrm{pl}$. IIa, figs. $\mathrm{x}-7$.

"The general form and contour of the cephalic shield closely resemble that of $I$. gigas DeKay; but the facial sutures do not converge in front to form a distinct angle, but describe three parts of a circle as in Asaphus expansus. The eyes are reticulated and the middle lobe of the caudal shield is defined (though sometimes somewhat indistinctly), but the segments are only obscurely pronounced. The glabella is but obscurely defined, and the genal angles are produced into spines. The thorax consists of eight segments.

From $I$. megistos, it differs in the eyes being set closer together; in the spines being longer, extending as low as the caudal shield; the pygidium more regularly elliptical, and its axial lobe more distinctly defined.

From the bituminous limestone mouth of Otter Creek, Turkey River, Iowa."

The original description, of which the above is practically a copy, is so incomplete that it seems advisable to redescribe the species in more detail.

Body subelliptical, length about twice the greatest breadth, moderately convex, trilobation not well developed. Entire surface finely punctate, the punctæ being larger and more pronounced on the free cheeks and less conspicuous on the marginal borders than on other parts of the test.

Cephalon semi-oval in outline, marginal border defined by a marginal furrow which originates on the genal spines. as an angular groove and develops into a shallow concave furrow gradually widening to the front of the glabella. Dorsal furrows shallow, converging toward the median line in passing the palpebral lobes, then diverging to about their original distance apart. Cranidium moderately convex, greatest convexity just in front of the eyes, concave where the marginal furrow crosses it. The anterior margin of the cranidium forms the margin of the cephalon. Fixed cheeks very small, not well defined. Free cheeks large, with long genal spines, convex near the eyes, not produced in front of the glabella. The facial sutures originate on the posterior margin of the cephalon about midway between the dorsal furrows and the lateral margins, from whence they converge forward in a sigmoid curve to the crest of the eye lobes, which they follow, thence forward and outward in an arcuate curve, meeting the anterior margin of the cephalon in front of the anterior angles of the eyes; here the sutures bifurcate, one fork following the anterior margin until it meets the 
fork from the other side in a continuous curve or slight angulation, never in a distinct angle; the other fork passes over the margin and curves across the doublure to the base of the hypostoma. (Pl. XIII, fig. 2.) Hypostoma forked posteriorly, only slightly constricted at the base, greatest width about three-fifths the length. Compared with I. gigas the forks point more directly backward making the notch between them narrower. Eyes lunate, prominent, situated less than their own length in front of the posterior margin of the cephalon, rather near together for the genus. A rather indistinct posterior cheek furrow extends across the fixed cheeks. Occipital ring and furrow obsolete.

Thorax composed of eight segments. Dorsal furrows shallow, illdefined; axial lobes depressed convex, not tapering, occupying more than one-third but less than one-half the width of the thorax; pleural lobes curving gently upward from the dorsal furrows, then more abruptly downward to the lateral margins; each segment arching gently forward on the axial lobe, and curving slightly backward towards the extremities of the pleuræ. A shallow concave furrow crosses the axial lobe, originating on the posterior margins at the dorsal furrows. A more pronounced subangular furrow originates on the anterior margin of each pleura at the dorsal furrows and passes diagonally outward and backward about three-quarters the length of the pleura. The distal portion of each pleura is distinctly flattened anteriorly. The flattening occupies nearly the entire width at the rounded extremity of the pleura but gradually narrows towards the dorsal furrow until it disappears.

Pygidium slightly narrower and longer than the cephalon, rather more convex, with a marginal border of uniform width. Axial lobe tapers abruptly near its anterior margin thereafter only moderately to its prominent, rounded termination, no annulations visible. The segmentation of the pleural lobes is obscure although three or four segments may be distinguished on young individuals. All markings are more distinct on young than on older individuals.

Measurements. The figured specimen (Mus. No. P Ir 24I) (Pl. XIII, fig. I) measures: Cephalon $36.5 \mathrm{~mm}$. long, $63.5 \mathrm{~mm}$. wide, thorax $33 \mathrm{~mm}$. long. Another (Mus. No. P 6969) measures: Cephalon 2I mm. long, $36 \mathrm{~mm}$. wide, thorax $18.5 \mathrm{~mm}$. long, $36 \mathrm{~mm}$. wide. Pygidium $24.4 \mathrm{~mm}$. long, $34 \mathrm{~mm}$. wide, entire length $63.9 \mathrm{~mm}$.

Remarks.- Specimens of this species have been usually referred to $I$. maximus Locke, but the writer is convinced that they belong to Owen's species as the Museum collection contains one nearly complete individual and quantities of less complete ones that were collected at the type locality which agree with Owen's description. The character which most easily distinguishes $I$. iowensis from $I$. maximus is the 
position of the facial sutures. In $I$. iowensis they follow the anterior margin of the cephalon and unite in a curve or indistinct angle. In I. maximus the sutures run subparallel to the anterior margin and meet in a distinct angle so that the free cheeks are produced in front of the glabella, while in $I$. iowensis the cheeks terminate in front of the eyes. Owen describes the genal spines as extending the entire length of the thorax, but his original figures show the spines much shorter. In the specimens before the writer the length of the spines seems to be a variable character.

Locality and horizon.- "Isotelus Zone" near the base of the Lower Maquoketa beds near where Otter Creek empties into Turkey River at Elgin, Iowa, and at Clermont, Iowa.

\section{Genus MEGALASPIS Angelin 1878 .}

Cephalon having its anterior portion large and flattened. Glabella short, more or less prominent, in front of which the facial sutures unite, usually, in a long drawn out point. Doublure of the cephalon divided by a median suture. Hypostoma arched, not forked, emarginate or drawn out in a point posteriorly. Thoracic axis small, pleuræ rounded at the ends. Pleuræ of the pygidium grooved, doublure of the pygidium narrow with a channel-like excavation. Range Ordovician, Europe and North America.

This generic description is adapted from Schmidt's* discussion of the Asaphidæ. Beecher $†$ makes the presence of a well-defined, cylindrical glabella the distinguishing feature of the genus, but a study of the various European species discloses the fact that the form and definition of the glabella are variable characters.

\section{Megalaspis Beckeri $\ddagger$ sp. nov. Plate XIV, Fig. 5.}

Type specimen in the collection of Mr. A. G. Becker.

General outline of the test subelliptical with its anterior margin produced into a long acuminate process, trilobation only moderately well developed. Entire surface appears smooth to the unaided eye, but under a lens, minute, rounded pustules are visible scattered over the surface. These pustules are larger and nearer together in the axial region, especially just in front of the glabella.

Cephalon subtriangular in outline, with all sides of the triangle concave, marginal border narrow and not well defined. The posterior portion of the cephalon is convex, the anterior portion flattened and

*Rev. Ostbaltischen Sil. Trilobiten Abt. V, lief. I and 4.

†Zittel-Eastman Text Book Pal:, p. 630

¥This name was proposed by Mr. E. O. Ulrich and the figure is from a photograph furnished by him. 
produced into a long acuminate process pointing obliquely upward. Dorsal furrows visible only in the occipital region. Glabella not defined laterally or anteriorly, depressed convex, greater elevation at its posterior margin, which is the greatest elevation of the entire test. Fixed cheeks not defined. Free cheeks large, widest near the eyes, where they slope abruptly to the lateral margins; the genal angles are produced into short spines, extending directly backward as far as the sixth thoracic segment; the anterior portions narrow gradually forward until they meet at the anterior margin. The facial sutures originate on the posterior margin of the cephalon about midway between the dorsal furrows and the genal angles, converging slightly to the eyes; in front of the eyes they converge more rapidly, extending subparallel to the antero-lateral margins of the cephalon and meeting in front of the glabella. The palpebral lobes are prominent, their proximal edges being produced towards the median line of the glabella and interrupting the dorsal furrows; the transverse ridges thus formed appear to be comparable to lateral glabella lobes rather than ocular ridges. Form of the eyes not known, but one of the palpebral lobes on a cranidium (Mus. No. P r 6998) indicates that they were elevated similar to those of Nileus vigilans. Occipital segment and furrow obsolete. Shallow posterior cheek furrows extend laterally from the dorsal furrows, meeting the lateral furrows near the genal angles.

Thorax composed of eight segments. Dorsal furrows shallow; axis depressed convex, slightly tapering posteriorly; occupying somewhat more than one-third the width of the thorax; no transverse furrows; the pleuræ curve outward and then abruptly downward to the lateral margins; distal extremities rounded; angular furrows originate at the dorsal furrows and cross the pleuræ diagonally.

Pygidium slightly narrower and much shorter than the cephalon, marginal border defined only near the posterior margin: Axis tapering to a prominent rounded termination well within the margin. The pleural lobes curve abruptly to the lateral margins. The segmentation of the pygidium is not visible on the outer surface of the test, but on its inner surface some traces may be found on both axis and pleure.

The measurements of the type specimen are as follows: Length over all $89.1 \mathrm{~mm}$.; width at genal angles $37.2 \mathrm{~mm}$.; length of the cephalon on median line $42.5 \mathrm{~mm}$.; length of cephalon including genal angles 57 mm.; length of thorax $21.3 \mathrm{~mm}$.; width of thorax at anterior segment $33 \mathrm{~mm}$.; length of pygidium $26.5 \mathrm{~mm}$.; width of pygidium at anterior margin $29.5 \mathrm{~mm}$.

So far as known to the writer, only two American species have been referred to this genus. These are $M$. ? gonioceras Meek from the 
Quebec group of Utah and $M$. belemnura White from a similar horizon in Nevada. These species were described from pygidia only, so that their reference is somewhat doubtful. Judging from the descriptions and figures of the above species, neither of them closely resembles the pygidium of $M$. beckeri; so that comparison must be made with European species. In general form $M$. beckeri most closely resembles $M$. extenuata Angelin from Gothland, Sweden, but is distinguished from that species by not having the glabella defined laterally or anteriorly, by having its genal spines less flaring and by having much narrower marginal borders of the pygidium.

The specific name is given in honor of Mr. A. G. Becker, whose collection contains the type specimen.

Localities and horizon.- The species is known to the writer by a practically complete specimen, the type, and a nearly complete cranidium (Mus. No. P I6998). The type is from the Lower Maquoketa beds at Clermont and the cranidium from a similar horizon at Postville Junction, Iowa.

\section{Genus NILEUS Dalman 1826 .}

"Corpus breve, convexum lave, sulcis dorsalibus longitudinalibus nullis; segmentis trunci 8. Oculi maximi, laterales." (Palceden oder die Sogenannten Trilobiten, p. 70. )

The above is Dalman's original description of the genus and may be somewhat elaborated as follows: Body elliptical, convex, smooth. Cephalon twice as wide as long, convex, genal angles broadly rounded. Glabella undefined laterally, no lateral furrows. The facial sutures originate on the posterior margin of the cephalon, curve forward to the eye lobes, over which they pass, thence with a sigmoid curve to the anterior margin, where they meet. Eyes large, lunate, holochroal. Rounded hypostoma with elevated border. Eight thoracic segments, indistinctly tri-lobed, axial lobe the broader. Pygidium twice as broad as long, neither lobed nor segmented, broadly rounded posteriorly. Range, Ordovician of Europe and North America.

Nileus vigilars Meek and Worthen Plate XIV, Figs. 9-I5.

A saphus vigilans M. \& W., Geol. Surv. Ills., Vol. VI, p. 497, pl. 23, fig. 6.

Nileus vigilans Clarke, Pal. Minn., Vol. III, pt. 2, p. 7I 2, figs. I 7-I 9.

Body convex, trilobation very obscure, subelliptical in outline, lateral margins nearly parallel. Surface smooth to the naked eye, but under a magnifier the extremities are ornamented with transverse 
impressed lines. These lines are most distinct on the doublure and anterior portion of the glabella and rather indistinct on the pygidium. Free cheeks finely punctate.

Cephalon sublunate in outline, somewhat depressed on the anterolateral margin, convex, frontal slope inflated but not projecting. Margin marked by a slight recurved elevation; genal angles obtusely rounded; free cheeks large, produced in front of the cranidium nearly or quite to the median line. Eyes small for the genus but prominent, situated at points each one-third the transverse diameter of the cephalon, and about their own diameter from the posterior margin. The facial sutures originate on the posterior margin of the cephalon at about onethird the distance from the dorsal furrows to the genal angles, curve obliquely forward over the palpebral lobes thence in sigmoid curves to the anterior margin, where they meet. Glabella furrows, dorsal furrows and occipital ring and furrow are obsolete on the surface of the test, but on casts the location of the dorsal furrows is indicated on each side by pits at the posterior margin of the cephalon. These pits are connected by a shallow occipital furrow, running parallel to the posterior margin until near the median point, where it arches forward.

Thorax composed of eight broad, flat segments, trilobation very obscure; axis about three-fourths the entire width, depressed convex; pleural lobes curving regularly to the lateral margins; segments arched slightly forward on the axial lobe, somewhat curved backward. On enrolled specimens this backward curve appears greater than it really is on account of the flattening of the anterior portion of the pleuræ, which originates at the dorsal furrows and gradually widens distally. On the anterior border at the dorsal furrow of each segment are small projections which point forward and fit into corresponding notches of the preceding segment. The segments are without grooves on the test, but on the casts a shallow groove connects the dorsal furrows.

Pygidium somewhat narrower but longer than the cephalon, depressed convex, sloping equally to the margins, trilobation and segmentation wanting on the surface of the test but faintly discernible on the casts.

Remarks. - The Maquoketa specimens, above described, appear to correspond in practically all points to the original description and are from a similar horizon to the type. The Galena and Trenton specimens referred to this species and described by Clarke appear to differ as follows: The facial sutures reach the margin of the cephalon in front of the eyes, while in the Maquoketa specimens the sutures reach the anterior margin near the median line of the cephalon. The front part. of the cranidium is more inflated in the Maquoketa specimens. 


\section{Field Museum of Natural History - Geology, Vol. IV.}

Locality and horizon.- This species was originally described from the Cincinnati shales of Carroll and Kendall Counties, Illinois. It has been collected by the writer from the Lower Maquoketa beds at Clermont, Elgin, and Bloomfield, Iowa, and Upper Maquoketa bed at Patterson's Springs near Brainard, Iowa.

\section{Genus BUMASTUS Murchison 1839.}

"General characters.-Pars anterior; capitis rotundato-convexa, subrqualis; oculis lunatis, glabris, remotis. Pars costalis s. corpus, sulcis longitudinalibus vix apparentibus, costis decem. Pars posterior maxima, rotundato-tumida, aqualis. Omnes testa partes ultro citroque, linearum sulcatarum subtilisimis ambagibus punctulisgue confertis, insignita." Silurian System I839, p. 656 .

(TRANSLATION)

Generic characters.- Anterior part; (cephalon) rotund, convexity of the head subuniform; eyes lunate, smooth, situated far apart. Segmented part of the body; (thorax) longitudinal furrows scarcely discernible, ten segments. Posterior part (pygidium) large, roundly, uniformly tumid. All parts of the test irregularly marked by impressed lines, interspaces finely and obscurely punctate.

The above is the original description of the genus. The author states later that the surface markings may be of only specific importance and that he has added them to the generic definition provisionally.

Bumastus beckeri sp. nov. Plate XIV, Figs. I-4.

Type specimens: holotype in collection of Mr. A. G. Becker, one paratype in collection of State University of Iowa, and the other No. P I6708 Field Museum.

Description.-Body oblong, slightly ovate, width at the genal angles about half the entire length. Dorsal furrows nearly obsolete on the cephalon and thorax and entirely so on the pygidium. Surface, except in the region of the palpebral lobes, dorsal furrows and the anterior central portion of the glabella, marked with indented, transverse lines, more or less parallel to each other and to the transverse divisions of the test. These lines are conspicuous and close together on the doublure, somewhat less so on the cephalon and anterior segments of the thorax. On the posterior segments and pygidium they are inconspicuous and only discernible with a magnifier.

Cephalon strongly convex, semicircular in outline; the location of the dorsal furrows indicated by two almost imperceptible grooves 
leading up to longitudinally elongate depressions situated just in front of a line joining the anterior edges of the eyes and somewhat nearer to the eyes than to the median line of the cephalon. These depressions appear as sublunate grooves on the casts, but on the surface of the test only as a slight flattening. The regular curvature of the cephalon, aside from the flattening just referred to, is interrupted only by the palpebral lobes. Eyes far apart, situated at about half their length from the posterior margin of the cephalon. Facial sutures originate on the posterior margin of the cephalon on a level with the lower edges of the eyes, from whence they pass forward and upward around the eyes, thence obliquely downward to the antero-lateral margin of the cephalon. Free cheeks small, genal angles obtusely rounded. Occipital ring not discernible on either test or cast.

Thorax composed of ten segments, smooth and flat, gradually narrowing to the almost obsolete dorsal furrows, at which points they bend backward and downward to the lateral margins; the axis occupies about two-thirds of the width of the thorax; dorsal furrows appear on the casts as two parallel grooves.

Pygidium strongly arched, transversely oval, length about twothirds the width, no trace of the dorsal furrows.

Five specimens were used by the writer in making this description. The holotype (Pl. XIV, fig. I) is an enrolled specimen having a portion of the front of the cranidium missing. It is in the private collection of Mr. A. G. Becker. A paratype (P1. XIV, figs. 2-3) consists of a complete cephalon attached to nine complete thoracic segments and a portion of the tenth. This specimen was collected by Prof. Calvin and is a part of the geological collection of the State University of Iowa. The other paratype (Pl. XIV, fig. 4) is a pygidium attached to the seven posterior thoracic segments. It belongs to the Museum collec-

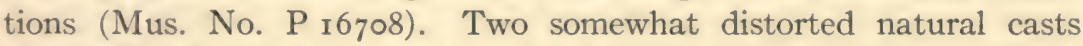
(Mus. No. P r6854) were also used in making this description. These casts were presented to the Museum by Mr. Becker. The dimensions of the type specimens are as follows: Holotype: Cephalon $18 \mathrm{~mm}$. long, $3 \mathrm{I} .5$ wide; pygidium $\mathrm{I} 5 \mathrm{~mm}$. long, $26.4 \mathrm{~mm}$. wide; distance around the coiled specimen $74.5 \mathrm{~mm}$. Allowing for the convexity of the cephalon and pygidium would make the length if unrolled about $60 \mathrm{~mm}$. Specimen from the State University of Iowa: Cephalon $19.6 \mathrm{~mm}$. long, $32.3 \mathrm{~mm}$. wide and $\mathrm{I} 8 \mathrm{~mm}$. thick. Specimen P I6708: Pygidium II $\mathrm{mm}$. long, $19 \mathrm{~mm}$. wide, length of pygidium and the seven posterior segments of the thorax $33 \mathrm{~mm}$.

Remarks. - Specimens of this species have been referred to $B$. orbicaudatus Billings by Calvin, Savage, and others in the various Iowa 


\section{Field Museum of Natural History - Geology, Vol. IV.}

reports. B. orbicaudatus was originally described* from a pygidium only and a complete specimen was afterwards $\dagger$ figured by Billings. Referring to this description and figure, it is evident that $B$. beckeri is quite distinct from $B$. orbicaudatus. The cephalon and pygidium are much longer in proportion to their width, and the dorsal furrows are much more distinct in $B$. orbicaudatus. The orbicular axis of the pygidium, which is the distinguishing character of $B$. orbicaudatus, is missing in $B$. beckeri. $B$. beckeri seems to be most closely related to $B$. billingsi Raymond and Narraway from the Trenton limestone of Canada, but it is considerably narrower in proportion to its length, the trilobation is much less pronounced and no mention is made in the description of $B$. billingsi of any transverse lines on the test.

The specific name is given in honor of Mr. A. G. Becker, whose collection contains the type specimen.

Locality and horizon.- All specimens observed are from the Lower Maquoketa beds of Clermont.

\section{Genus THALEOPS Conrad 1843 .}

"Ovate, profoundly trilobed, lateral lobes wider than the middle lobe; buckler (cephalon) lunate, with very remote oculine tubercles, not reticulated; abdomen (thorax) with Io-articulations; ribs without grooves and not alternated in size; outer half of lateral lobes suddenly depressed; post-abdomen (pygidium) without ribs or grooves and profoundly trilobed."

"This genus is remarkable for the great width of the buckler, and the very prominent laterally projecting smooth oculine tubercles. It differs from Bumastus in being profoundly lobed, and in having the side lobes as in Asaphus much wider than the middle lobe. From Illanus it may be distinguished by its ovate form, want of reticulated eyes, the width of the lateral lobes, and the profound lobes of the tail." Proc. Acad. Nat. Sci. Phil., I 843, Vol. I, p. 33r.

The above is Conrad's original description of the genus and to it should be added that the free cheeks are produced laterally at the genal angles into blint spines.

Thaleops ovata Conrad, Plate XIV, Figs. 6-8.

T. ovata Conrad, I843. Proc. Acad. Nat. Sci. Phil., Vol. I, p. 332. Illanus ovatus Whitfield, I882. Geol. Wis., Vol. IV, p. 238, pl. 5, figs. $\mathbf{I}-2$.

*Can. Nat. Geol., Vol. iv, p. 379.

†Cat. Sil. Foss. Anticosti, p. 27. 
T. ovata Clarke, 1897. Pal. Minn., Vol. III, pt. 2, p. 716, figs. r7-I9. Body broadly ovate, widest at the base of the cephalon, distinctly trilobed, length about equal to the width at the eye lobes.

Cephalon broadly semicircular on the anterior margin, very. highly convex. Dorsal furrows clearly defined on the posterior third of the cephalon, obsolete in front. Glabella convex between the dorsal furrows, not defined in front. Eyes small, pedunculate, extending laterally and horizontally. Occipital segment and furrow very faintly marked, rounded backward. Free cheeks small, produced laterally at the genal angles into blunt spines. The facial sutures rise rapidly from the posterior margin to the summit of the eye lobes, thence round gradually forward to the anterior margin, which they intersect in front of the dorsal furrows.

Thorax wider than long, tapering, composed of ten smooth, slightly convex segments. Axial lobe depressed convex, narrower than the lateral lobes, "segments arched forward. Pleuræ flat for more than half their width from the axis, then bent downward, segments strongly recurved toward their extremities.

Pygidium nearly flat on top and curving abruptly to the margins, short, subquadratic. The posterior margin forms a very broad curve, width about twice the length. Axis prominent, narrower than the thoracic axis, tapering slightly and terminating bluntly in an elevated extremity, which is faintly bilobed; axis entirely surrounded by the dorsal furrows; annulations of the axis nearly obsolete.

The surface of the cephalon is covered with epidermal punctæ except in the dorsal furrows and on the palpebral lobes. On the cheeks and anterior portion of the glabella the punctæ are vertical and isolated, on the posterior surface of the glabella they are oblique and crowded. The surface of the thorax appears to be smooth. Doublure marked with prominent lines parallel to the anterior margin. Pygidium sparsely punctate on the posterior margin but on the anterior portion the punctations are deep, coarse, and arranged in transverse rows.

The foregoing description is based on a practically complete specimen from the Platteville beds at Mineral Point, Wisconsin, in the paleontological collection of the University of Chicago. The Fayette County specimens have been compared with the Platteville specimen and agree so well that they must be considered to be specifically identical, although previously $I$. ovata has been found only at lower geological horizons.

This species is represented in the Museum collections from Fayette County by a nearly complete cranidium from the Lower Maquoketa at Clermont and another from the Upper Maquoketa at Patterson's Springs. 


\section{Family LICHADID $Æ$, Barrande.}

Genus AMPHILICHAS Raymond 1905.

\section{(Platymetopus* Angelin I854, Paralichas Reed I902.)}

By combining the various characters enumerated in previous descriptions this genus may be described as follows:

Cephalon broadly subtriangular, tuberculate. Anterior lobe of the glabella dominating the other lobes, and continuous with the axis; a single pair of lateral glabella furrows opening directly into the occipital furrow; no third lobes; all lobes depressed convex, all furrows narrow; dorsal furrows concave inward; occipital ring forming a band. Pygidium with two rings on the axis; post-axial piece not defined posteriorly; three pairs of pleuræ, each with pleural furrow and free point; third pair incompletely defined from post-axial piece, points short and blunt.

\section{Amphilichas RHinoceros sp. nov. Plate XV, Figs. 5-6.}

Type specimen No. P i I 8 8 Field Museum.

Glabella large, occupying nearly the entire width of the cranidium, depressed convex posteriorly, inflated in front, subpentangular in outline, rounded anteriorly, greatest width just in front of the eyes; the single pair of glabella furrows originates on the lateral margins, curves gently inward and backward for about half the length of the glabella, thence backward subparallel until they join the occipital furrow. They thus divide the glabella into a median and two lateral lobes. Median lobe broad in front, posterior half only slightly convex, anterior half abruptly inflated, length about two and one-half times the width at the occipital furrow. Lateral lobes undivided, margins subparallel, width about equal to that of the median lobe, moderately convex except in front where they bend outward and downward to the lateral margins; greatest elevation near the dorsal furrows in line with the palpebral lobes, where large nodes rise abruptly from the dorsal furrows but elsewhere gradually; these nodes form the bases of the two, long, lateral spines. The occipital segment forms a wide, depressed, transverse band, widest in the middle and gradually narrowing towards the dorsal furrows; posterior margin slightly concave, with a well developed doublure. Dorsal furrows, as well as glabella and occipital furrows, narrow but well defined. Fixed cheeks small, depressed, convex, aside from the palpebral lobes, which rise abruptly; the only portion of the palpebral

*Platymetopus Angelin, 1854, preoccupied by Dejean, 1829, for genus of Coleoptera. Paralichas Reed, I902, suggested in its place, preoccupied by White, 1859, also for Coleoptera. 
lobes observed is that attached to the fixed cheek. This is elevated, lunate in form with the convex side toward the dorsal furrows. The marginal border of the cephalon is represented only by a single somewhat crushed fragment, but this fragment indicates that there was a narrow marginal border similar to that of $A$. bicornis Ulrich. Eyes and free cheeks not preserved. Surface of the cephalon finely papillose, with tubercles of various sizes more or less regularly arranged thereon. Two of the larger of these tubercles occur along the median line of the glabella, one on each lateral lobe, and three form a transverse row on the occipital segment; aside from these tubercles, the inflated anterior portion of the glabella supports a pair of recurved hornlike processes, $2.5 \mathrm{~mm}$. in diameter and $29 \mathrm{~mm}$. long (measured on the outer side of the curve); these processes diverge somewhat and curve upward, then backward. Another pair of processes of about the same size occurs; one on each lateral lobe of the glabella, near the dorsal furrow, in line with the eyes. Exact length of the lateral pair of processes not known.

Thorax and pygidium unknown.

The specimen (Mus. No. P III8I) on which the above description is based consists of a nearly complete cranidium of which the inner surface of the test is exposed with one of the anterior horns complete and in natural position and one of the lateral ones bent outward with the end missing. The dimensions are as follows: Length of cranidium, along the median line, $32 \mathrm{~mm}$.; greatest width of glabella (in front of eyes) $42 \mathrm{~mm}$.; width of median glabella lobe on anterior margin $18 \mathrm{~mm}$.; width at occipital furrow II.5 mm.; width of lateral lobes II.5 mm.; width of occipital segment on median line $7 \mathrm{~mm}$.; width at dorsal furrows $5.5 \mathrm{~mm}$.

Remarks.- In general form and proportion the cranidium above described approaches $A$. bicornis Ulrich, from a similar horizon in Minnesota, but is distinguished from that species by the number and position of the hornlike processes as well as by the variation in size of the surface tubercles; also in a side view of the glabella of $A$. bicornis the outline of the surface is convex, while in A. rhinoceros the outline near the middle is concave, due to the inflation of the anterior portion.

Locality and horizon.- Upper layers of the Lower Maquoketa beds at Elgin, Iowa.

Amphilichas clermontensis sp. nov. Plate XV, Fig. 7 .

Type specimen No. P I 257 Field Museum.

Cephalon subtriangular, broadly rounded anteriorly, much shorter in proportion to the width than $A$. rhinoceros. Glabella convex, great- 
est elevation just in front of the center, to which point it rises gradually from the posteror and lateral margins and much more abruptly anteriorly; subpentangular in outline, widest in front of the eyes; a single pair of glabella furrows originates on the lateral margins, curves abruptly inward and upward, then converges backward until it meets the occipital furrow, forming a large median lobe and two smaller lateral lobes. Median lobe very broad anteriorly, more than twice the width at the occipital furrow. It comprises nearly two-thirds of the glabella. Lateral lobes undivided, margins subparallel, conforming to the general convexity of the glabella, abruptly bent downward anteriorly. Occipital segment a flat or slightly concave, transverse band, widest at the juncture of the occipital and glabella furrows, narrowing slightly to the median line and more so laterally. Occipital and glabella furrows narrow but distinct. Surface smooth to the naked eye, but a magnifier shows it to be covered with variously sized pustules. No nodes or spines interrupt the regular curvature of the cephalon.

Thorax and pygidium unknown.

The specimen here described (Mus. No. P II257) consists of an incomplete glabella. The cheeks and marginal border are entirely missing. The median lobe and one lateral lobe are nearly complete, and the other lateral lobe is somewhat less so. The occipital, one dorsal and the glabella furrows are well indicated and the median portion of the occipital segment is intact. While the specimen leaves much to be desired, yet the generic characters are well shown and the specific characters fairly well.

The dimensions are as follows:

Length of glabella on median line (exclusive of occipital

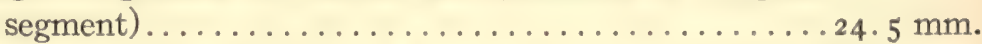

Greatest width of glabella (in front of the eyes) ..... $\mathrm{mm}$.

Width of glabella at occipital furrow............ $\mathrm{mm}$.

Width of median glabella lobe on anterior margin, about. .24 $\mathrm{mm}$.

Width of median glabella lobe on occipital furrow...... I I $5 \mathrm{~mm}$.

Width of lateral glabella lobes................ $8.5 \mathrm{~mm}$.

Length of lateral glabella lobes............... $\mathrm{m} 7 \mathrm{~mm}$.

Width of occipital segment on median line........ $3.5 \mathrm{~mm}$.

Width of occipital segment behind glabella furrows . . . 4.2 $\mathrm{mm}$.

Amphilichas clermontensis is distinguished from the other members of this genus by the much greater width of the glabella in proportion to its length and by its more nearly arcuate curvature both longitudinally and transversely. In surface ornamentation it resembles $A$. circullus from the Trenton, but in form it is quite distinct from that species.

Locality and horizon.-Lower Maquoketa beds, Clermont, Iowa. 


\section{Order PROPARIA.}

\section{Family ENCRINURIDÆ, Linnarsson.}

\section{Genus ENCRINURUS Emmrich I844.}

"Cephalon tuberculate; glabella pyriform, prominent; free cheeks narrow, separated in front by a small rostral plate; eyes small, elevated on conical prominences; thoracic segments eleven; pygidium triangular, numerous annulations on the axis; pleuræ with few ribs." Range, Ordovician and Silurian, Europe and America. (Zittel-Eastman Text Book Pal., p. 634.)

Vogdes* divided the above genus by placing all species without genal spines in Cryptonymus Eichwald, but his point does not appear to be well taken for two reasons. (I) In I825 Eichwald described the genus Cryptonymus with $C$. scholotheimi as genotype. Seven other species were placed in the genus. The genotype and three others were found to belong to the genus Asaphus Brong., the balance to Illanus Dahlman. In 1840 Eichwald again used the name Cryptonymus for a genus entirely different from the one described in 1825 , thus using a preoccupied name. (2) The presence or absence of genal spines does not appear to the writer to be of generic importance.

\section{Encrinurus Pernodosus sp. nov. Plate XVI, Figs. 5-7.}

Type specimens Nos. P I 7038 and P I6930 Field Museum.

Body ovate in outline, trilobation distinct, without genal or caudal spines.

Cephalon sublunate in outline, anterior margin inflated, width more than twice the length. Glabella subhemispherical, width somewhat less than the length, slightly protruding beyond the anterior margin; three pairs of indistinct lateral glabella furrows define the lateral lobes; these furrows rapidly decrease in depth from the dorsal furrows and become obsolete among the tubercles; a well-defined furrow originates on the dorsal furrows about midway between the anterior lateral glabella furrows and the anterior marginal furrow and bends slightly forward in crossing the anterior lobe of the glabella; anterior glabella lobe large, comprising nearly half the glabella, lateral lobes quadrangular, decreasing rapidly in size posteriorly; occipital segment narrow, resembling the axial portion of one of the thoracic segments in size and form; occipital furrow narrow, angular, well-defined; dorsal furrows deep, angular, diverging somewhat from the occipital furrow to the anterior

*Trans. San Diego Soc. Nat. Hist. Vol. I, No. 2, p. 74. 


\section{Field Museum of Natural History - Geology, Vol. IV.}

marginal furrow; cheeks subtriangular in outline, depressed conical in form, sloping gradually to the palpebral lobes; eyes small, pedunculate, holochroal; facial sutures originating at the genal angles, passing directly to the palpebral lobes, which they cross, thence obliquely forward, crossing the dorsal furrows and subparallel to the furrow crossing the glabella, until they meet the rostral plate, where they bend abruptly forward to the anterior margin; free cheeks large, more than twice the size of the fixed cheeks; marginal borders well-defined by the marginal furrows, those of the posterior margin narrow, those of the lateral margins wide, gradually narrowing to the anterior margin; genal angles rounded, ending in a large tubercle. Surface of the glabella covered with large rounded tubercles, that of the cheeks near the dorsal and lateral marginal furrows tubercular, other portions covered with elongated pits radiating from the eyes; surface of the occipital segment and marginal borders finely granulose. Hypostoma broadly elliptical, convex.

Thorax composed of eleven segments; axis convex, about the same width as the pleuræ; tapering slightly posteriorly, pleuræ curving regularly to the lateral margins; surface of the thoracic segments finely granulose, ornamented with indistinct nodes; these vary from two to four on the axis and one or two on each pleura; no pleural grooves.

Pygidium triangular, convex, width somewhat greater than the length, rounded posteriorly, no caudal spines. Axis convex, conical, occupying about one-third the anterior margin of the pygidium, with many annulations, which diminish in size and distinctness posteriorly so that the number visible depends to a great extent on the amount of abrasion to which the specimen has been subjected; most of the annulations bear two to four rounded nodes, having decided pits in their apices. Pleuræ composed of seven distinct ribs, which curve slightly upward and then downward and backward to the margins; each rib ornamented with two or more rather indistinct nodes near the dorsal furrows and with a prominent knoblike distal end.

Dimensions of the type specimen:

Length of cephalon....................

Width of cephalon at genal angles............... $7.5 \mathrm{~mm}$.

Length of glabella exclusive of occipital segment....... $8.4 \mathrm{~mm}$.

Width of glabella on anterior margin........... $8.0 \mathrm{~mm}$.

Width of glabella on occipital furrow............ $5.0 \mathrm{~mm}$.

Entire length of body measured on a coiled specimen... $32.0 \mathrm{~mm}$.

Length of pygidium (Mus. No. P I6930) ......... $8.2 \mathrm{~mm}$.

Width of pygidium..................... $9.6 \mathrm{~mm}$.

Width of axis at anterior margin.............. $3.6 \mathrm{~mm}$. 
The species is known from the holotype (Mus. No. $\mathrm{P}_{17}$ 7038) in which the cephalon, about two-thirds of the thorax and most of the pygidium are preserved, from five detached pygidia and from one specimen in which the entire pygidium is attached to all but the anterior segment of the thorax.

In general form and proportions the species here described resembles E. variolans, Brongniart from the Wenlock Limestone of England, but the tubercles are much larger, the transverse furrow on the glabella is missing and the annulations of the pygidia are fewer in number. $E$. sexcostatus Salter possesses the transverse furrow, but that seems to be about the only resemblance with this species.

Locality and horizon.- The holotype is from the top of the Lower Maquoketa beds at Bloomfield. The species has been found at a similar horizon at Clermont and Elgin, and at a somewhat lower horizon at Clermont.

\section{Genus CYBELOIDES gen. nov.}

Body distinctly trilobate, outline, aside from the spines, sub-ovate. Cephalon sub-lunate; genal angles produced into spines. Glabella divided by two longitudinal furrows into a central and two lateral lobes; the lateral glabella furrows are indicated by three pits situated in each longitudinal furrow. Eyes small, pedunculate; the facial sutures originate on the lateral margins somewhat in front of the genal angles. Thorax consists of twelve segments; the five anterior segments are faceted at their distal extremities. The sixth segment, and in some specimens the sixth to the twelfth, is abruptly bent backward at the lateral margin of the thorax and produced into long spines. Pygidium small, axis conical with many annulations, pleural lobes with few ribs.

Genotype, Cybeloides iowensis. Range, Ordovician of North America.

This genus differs from Cybele Loven as exhibited in C. bellatula, the genotype, in the form of the glabella furrows and in the genal angles being produced into spines instead of being rounded.

Four American species have been referred to the genus $C y b e l e ; C$. ella Narraway and Raymond, $C$. prima (including $C$. valcourensis) Raymond, $C$. winchelli Clarke, and a portion of a pygidium referred to the genus without specific determination by Ruedemann. Of the first two only is the form of the glabella known, but both of these agree with C. iowensis here described. Narraway and Raymond called attention to the difference of the form of the glabella of this species from that of the European species, but still referred their species to $C y b e l e$. While the 
64 Field Museum of Natural History - Geology, Vol. IV.

presence or absence of genal spines would not be of generic importance, the fact that the glabella is divided longitudinally into three lobes appears to be ample reason for separating the American from the European species generically. This is the character which distinguishes Chasmops from Dalmanites and the various genera of the Lichadæ are based on the variations of the glabella furrows.

Of the eleven European species of Cybele known to the writer, two have only the pygidium described or figured; the other nine all have well-marked lateral glabella furro vs. Three of these species described by Schmitz, viz., C. grewingki, C. kutorga and C. revaliensis, exhibit a tendency toward the American forms. The lateral furrows are separated from the dorsal furrows by a narrow lateral margin of the glabella, but there are no traces of longitudinal glabella furrows.

The bibliography of the genus is as follows:

Cybeloides ella Narraway and Raymond.

I906 Cybele ella N. \& R., Ann. Carnegie Mus., Vol. 3, No. 4, p. 598, fig. I. Black River, Ottawa, Canada.

Cybeloidesiowensis Slocom, genotype this paper. Lower Maquoketa, Iowa.

Cybeloides prima Raymond.

I905 Glaphurus primus Raymond, Ann. Carnegie Mus., Vol. 3, No. 2, p. 362 , pl. I4, figs. $7-8$.

I905 Cybele valcourensis Raymond, ibid p. 362, pl. I4, fig. 9.

I906 Cybele prima Narraway and Raymond, Ann. Carnegie Mus., Vol 3 , No. 4, p. 6oI. Chazy, N. Y.

Cybeloides ? winchelli Clarke.

I897 Cybele winchelli Clarke, Pal. Minn., Vol. 3, pt. 2, p. 742, fig. 59. Galena Limestone, Minn.

Cybeloides? sp. ? Ruedemann.

I9or Cybele sp. ? Ruedemann, N. Y. St. Mus. Bull. 49, p. 66, pl. 4, fig. I2. Trenton, N. Y.

The last two species are placed in the genus provisionally until the characters of the glabella are known.

Cybeloides iowensis sp. nov. Plate XVI, Figs. I-4.

Type specimens Nos. P I663I, I6633 and I7039 Field Museum.

Body depressed convex, distinctly trilobed, outline, aside from the spines, subovate, tapering rather rapidly to a small pygidium. Surface finely granular with many more or less prominent rounded nodes.

Cephalon short, width nearly three times the length, outline sublunate with the anterior lateral margins inflated. Glabella convex, inflated anteriorly, somewhat longer than wide, widest across the 
lateral lobes; median lobe clavate, narrow at the occipital furrow, gradually widening for about half its length then abruptly widening until its greatest width is reached, rounded in front; lateral lobes longitudinally oval; longitudinal glabella furrows originating in deep pits on the occipital furrow, converging slightly, then curving forward and outward; the positions of the lateral glabella furrows are indicated by three pits in the longitudinal furrows; occipital ring prominent, more elevated than any other part of the cephalon, wide between the glabella furrows, abruptly narrowing towards the dorsal furrows, bearing a large median node with a smaller one on each side of it; occipital furrow shallow and ill-defined in the median portion, deepened into pits near the dorsal furrows. Surface of the glabella finely granular with many prominent rounded nodes arranged in more or less uniform transverse rows; the two largest nodes are close together near the anterior margin and point forward. On the median line of the glabella just in front of a line connecting the anterior pair of glabella pits is a circular, wellmarked pit. Cheeks large, depressed convex, not rising as high as the glabella, genal angles produced into long spines, which extend backward more than half the length of the thorax. Marginal borders convex; posterior marginal furrows narrow and deep, lateral marginal furrows not well-defined. The facial sutures originate on the lateral margin just in front of the genal angles, pass almost straight to the palpebral lobes, after crossing which they extend forward for a short distance, then curve abruptly toward the median line and again forward to the anterior margin. Eyes small, pedunculate and very prominent (Pl. XVI, fig. 4), situated on a line with the anterior pair of glabella pits near the dorsal furrows; a pair of ocular ridges connects the eyes with the anterior lobe of the glabella. Surface of the cheeks inside the marginal borders reticulated, or covered with rows of pits; surface of the marginal borders granular like the glabella, many nodes irregularly distributed over the cheeks; these nodes average somewhat larger than those on the glabella; the larger ones are on the posterior margin and point backward instead of outward.

Thorax composed of twelve segments, rather rapidly tapering posteriorly, distinctly trilobed; axis convex, less than one-third the width of the thorax; the pleural lobes curve gently for about half their width and then more rapidly to the lateral margins. Each segment is divided unequally by a furrow extending nearly from one margin of the thorax to the other. The posterior portion, which is the wider, bears numerous nodes, four of which occur on the axis and two or more on each pleura. The nodes on the pleuræ are much larger than those on the axis and their location on different segments is not always uniform. The 
five anterior segments terminate at the lateral margins of the thorax, but the seven posterior ones are abruptly bent backward at the lateral thoracic margins and are produced into spines. The spines of the sixth segment extend more than one-third their length beyond the pygidium; the spines of the other segments are considerably shorter.

Pygidium small but too poorly preserved in the specimens at hand for a detailed description.

The dimensions of the type specimens are as follows:

Length of the holotype along the axis $23.6 \mathrm{~mm}$. Length of body, including pleural spines, $31.3 \mathrm{~mm}$; width at genal angles $19.6 \mathrm{~mm}$.; length of cephalon, including genal spines, $16 \mathrm{~mm}$.; length of glabella 7.8 $\mathrm{mm}$.; width of anterior portion of glabella $4.7 \mathrm{~mm}$.; ditto across lateral lobes, $5.3 \mathrm{~mm}$.; length of thorax $\mathrm{r} 2.8 \mathrm{~mm}$.

Width of paratype at genal angles $27.8 \mathrm{~mm}$.; length of glabella 10.7 $\mathrm{mm}$.; width of posterior portion $8.0 \mathrm{~mm}$.; ditto across lateral lobes, 8.7 $\mathrm{mm}$.

This description is based upon the holotype (Mus. No. P I663I, P1. XVI, fig. I), a nearly complete specimen, a practically complete cephalon (Mus. No. P I 7039, P1. XVI, figs. 2-3), somewhat larger than the holotype, and a detached free cheek with eye (Mus. No. P.I6633, Pl. XVI, fig. 4).

Localities and horizon.- The holotype was collected by the writer from the top of the Lower Maquoketa beds at Elgin, the two paratypes from a similar horizon at Bloomfield. More or less complete cranidia are not uncommon at a similar and somewhat lower horizon at Clermont.

\section{Family CALYMENID $Æ$, Brongniart}

Genus CALYMENE Brongniart I822.

"Complete body sub-oval in outline, possessing the power of complete enrollment; cephalon sub-crescentiform with thickened margin, genal angles usually rounded; glabella strongly convex, narrowed in front, with three pairs of deep lateral furrows; occipital segment well defined; posterior limb of the facial sutures originating just in front of the genal angles; free cheeks elongate, separate, usually with a free plate between their anterior extremities in front of the glabella; eyes small; hypostoma sub-quadrate, notched. Thorax with thirteen segments; axis strongly convex and bounded by deep axial furrows; pleural lobes wider than the axis, bent down laterally. Pygidium distinctly marked off from the thorax, with six to eleven segments, axis prominent and margin entire." (Weller, Pal.Chicago Area, p. 26I.) 
Calymene fayettensis sp. nov. Plate XVI, Figs. 8-9.

Type specimen No. P I6755 Field Museum.

Body strongly trilobate, subovate in outline, greatest breadth at the genal angles, narrowing gradually to the anterior border of the pygidium, thence abruptly to the posterior extremity of the pygidium. Surface finely papillose with small rounded tubercles more or less regularly distributed thereon.

Cephalon sublunate in outline, anterior border arcuate, except between the anterior limbs of the facial sutures, where it is somewhat produced. Glabella moderately convex, not prominent anteriorly, slightly elevated above the cheeks, well defined by the dorsal furrows, broadest across the posterior lobes where the width nearly equals the length, gradually narrowing towards the front, which is truncated; frontal lobe quadrangular, occupying less than one-fourth the length of the glabella; first lateral lobes small, hardly separated from the frontal lobes; second lateral lobes larger and nodelike; posterior lobes much larger, forming a pair of conspicuous nodes at the base of the glabella. The lateral furrows do not cross the glabella, first pair indistinct, transverse; second pair well defined and bent backward; posterior pair broader and deeper than second pair, curved backward so as to nearly, but not quite, isolate the posterior lobes; occipital furrow arched forward in the middle, somewhat deeper and narrower back of the posterior glabella lobes, where it merges into the posterior cheek furrows; occipital segment prominent, widest in the middle, gradually narrowing to the dorsal furrows. Cheeks convex, with rounded lateral and sharp posterior marginal borders, greatest elevation at the palpebral lobes; marginal borders defined by shallow, concave furrows; free cheeks subtriangular, about half the size of the fixed cheeks. Facial sutures originate at the genal angles which they unequally bisect; from thence they pass obliquely forward until opposite the posterior glabella furrow; thence curve abruptly over the eye lobes to the anterior border, which they cut almost in front of the eyes. A small free plate to which the hypostoma is attached occupies the space between the anterior extremities of the sutures. Eyes small, lenses not preserved, situated well forward, about opposite the second glabella furrows.

Thorax composed of thirteen segments, length about three-fifths the entire length of the test, strongly trilobed; segments arched forward on the axis, each one bearing a pronounced rounded node on either side just within the dorsal furrows, and a smaller, more pointed one on each pleura, pointing forward, situated on the anterior margin at the crest of the convexity, when the body is rolled up; on the posterior margin is a notch or indentation into which the node from the next posterior seg- 


\section{Field Museum of Natural History - Geology, Vol. IV.}

ment fits; each pleura is provided with a well-marked groove which originates at the dorsal furrow and extends on to the flattened distal portion of the segment. The pleural segments curve regularly upward for about one-third their length, then abruptly to the lateral margins.

Pygidium transversely suboval in outline with posterior portion produced into an obtuse angle, strongly trilobed. The convex axis tapers posteriorly and terminates on a rounded extremity near the posterior margin, marked by seven annulations. The pleural lobes slope abruptly from the dorsal furrows to the margins, each lobe consisting of five or more segments, the anterior ones being distinct and the others becoming less so until they are entirely obsolete at the posterior extremity of the pygidium; each segment is marked by a shallow longitudinal groove which originates at the lateral margins and becomes obsolete before the dorsal furrow is reached.

The dimensions of the type specimen are: Length of cephalon ro.5 $\mathrm{mm}$.; width $\mathrm{I} 8.3 \mathrm{~mm}$.; length of thorax $2 \mathrm{I} .5 \mathrm{~mm}$.; length of pygidium $3.5 \mathrm{~mm}$; width $9.3 \mathrm{~mm}$.; entire length of the body $39 \mathrm{~mm}$. measured around an enrolled specimen, but if the test was unrolled it would measure 3 or $4 \mathrm{~mm}$. less. The cephalons of two specimens in the collection of Mr. A. G. Becker measure respectively $13.5 \mathrm{~mm}$. long, $24 \mathrm{~mm}$. wide, and $9.5 \mathrm{~mm}$. long, $15.6 \mathrm{~mm}$. wide. All of the specimens on which the description is based are enrolled specimens so that it is difficult to take accurate measurements of some of the parts.

Remarks.- This species has been referred by most writers and collectors to $C$. senaria of the Ohio Valley region, but upon comparing practically perfect specimens from the two localities they are found to be distinct. The glabella in $C$. senaria is shorter and more convex, the pleural segments of the pygidium do not have a longitudinal furrow, the lip-like process on the anterior margin of the glabella is shorter and the surface of the test does not possess the rounded tubercles. C. mammillata was described from the Maquoketa of Dubuque Co., Iowa, and specimens from the type locality loaned to the Museum for study from the collection of the State University of Iowa by Prof. George F. Kay prove $C$. fayettensis to be quite dissimilar. The frontal lip is very large in C. mammillata and bears a low, rounded tubercle just in front of each dorsal furrow. The surface ornamentation is also quite different. C. fayettensis resembles $C$. christyi in the outlines of the glabella, but there the similarity ceases as it does not possess the genal spines or the curvature of the thoracic segments, and the form and size of the pygidium are entirely unlike. The surface ornamentation of $C$. fayettensis is similar to that of $C$. niagarensis, but in the form of the glabella and many other characters it is entirely distinct. 
Locality and horizon.- The type (Mus. No. P r6755) was collected by the writer in July, I9I0, in the Lower Maquoketa shale at Clermont, Iowa. Other specimens were collected by the writer from the Lower Maquoketa beds at Clermont, Elgin, and Bloomfield, Iowa.

\section{Calymene gracilis sp. nov. Plate XVIII, Fig. 9.}

Type specimen No. P I 7065 Field Museum.

Body small, in form and general proportions similar to other species of the genus. The surface of the test appears smooth to the naked eye but under a magnifier it appears very finely papillose.

Cephalon sublunate, width of the genal angles somewhat less than twice the length on the median line, about as $7: 4$. Anterior border flat, projecting obliquely forward and upward, not recurved; separated from the glabella by a deep, narrow, marginal furrow. The dorsal furrows, in passing forward from the occipital ring, diverge slightly near the posterior glabella lobes, then converge until they meet the anterior marginal furrow. Here the dorsal furrows become nearly obsolete on account of a large rounded node on each fixed cheek, opposite the anterior lobe of the glabella. Glabella convex, elevated above the cheeks, shorter than is usual in this genus, widest at the posterior lobes where the width is equal to the length, including the occipital ring, much narrower anteriorly; anterior lobe transverse, width less than one-third the length; first lateral lobes well defined, about the width of the anterior lobe and terminating about the same distance from the median line; second lateral lobes larger and node-like; posterior lateral lobes much larger, forming a pair of conspicuous nodes at the base of the glabella. Lateral furrows well defined but not crossing the glabella. The first pair transverse; second pair somewhat larger, but bent slightly backward; posterior pair broader and deeper, curved backward towards, but not reaching, the occipital furrow; at about two-thirds of their length from the dorsal furrows they bifurcate; the shorter fork extends toward the median line of the glabella, forming a well-defined node between the second and posterior lobes. The facial sutures originate just in front of the genal angles, curve forward and inward over the palpebral lobes and thence forward to the anterior margin. Occipital ring prominent, slightly wider in the middle, separated from the rest of the glabella by a well-defined occipital furrow. Cheeks only moderately convex aside from the palpebral lobes, which are long for this genus and rise very abruptly from the dorsal furrows; lateral marginal borders wide and well rounded, posterior border much narrower; all are defined by deep marginal furrows. 
Thorax known only by a few detached segments which indicate that it was narrow and elevated.

Pygidium subtriangular, terminating in a rounded obtuse angle, strongly elevated and trilobed. Axis convex, marked hy six or seven annulations; it tapers gradually and is truncated posteriorly so that the dorsal furrows instead of meeting at a point posteriorly are joined by a short transverse furrow; the pleural lobes slope abruptly from the dorsal furrows to the margins; each lobe consists of five segments, faintly grooved on their distal portion; the segments merge into a smooth, undefined, marginal border.

The type specimen is a perfect cranidium with the following dimensions: Length on median line $7.8 \mathrm{~mm}$.; length including genal angles $9.0 \mathrm{~mm}$.; width $14.0 \mathrm{~mm}$.; length of glabella including occipital ring 5.4 $\mathrm{mm}$.; length of glabella without occipital ring $4.5 \mathrm{~mm}$.; width of glabella at anterior lobe $3.5 \mathrm{~mm}$; width of glabella at posterior lobes 5.4 $\mathrm{mm}$. A detached pygidium gives the following measurements: Length $3.4 \mathrm{~mm}$.; width $6.4 \mathrm{~mm}$.; thickness $4.8 \mathrm{~mm}$.

Remarks. - This species was considered by Savage to be identical with Calymene fayettensis of the lower beds, but it is distinguished from. that species by its surface ornamentation, its shorter glabella, its larger anterior margin, its longer and more prominent palpebral lobes, the transverse furrow connecting the dorsal furrows on the pygidium and its smaller size. In surface ornamentation this species resembles $C$. senaria but is distinguished from it by its longer palpebral lobes, its relatively short and more elevated glabella. It is distinguished from all species known to the writer by the nodes, which are situated in the dorsal furrows on each side of the anterior lobe of the glabella. $C$. mammillata bears two nodes, but they are situated on the anterior margin.

Locality and horizon. - Limestone layers of the Upper Maquoketa beds at Patterson's Springs near Brainard, Iowa. No complete specimens have been observed by the writer, but cranidia, free cheeks, thoracic segments and pygidia are comparatively abundant.

\section{Family CHEIRURID $Æ$, Salter.}

\section{Genus CERAURUS Green I832.}

"Entire body subovate in outline. Cephalon subsemicircular or subsemielliptical in outline, genal angles produced into spines; glabella strongly convex, broadest in front, with three pairs of deep lateral furrows; posterior limbs of the facial sutures cutting the lateral margins 
well in front of the genal angles; eyes small. Thorax usually with eleven segments, rarely nine to thirteen; axis prominent, narrower than the pleura, bounded by strong axial furrows. Pygidium small, pleural segments produced into points or spines." (Weller, Pal. Chicago Area, p. 263.)

\section{Ceraurus pleurexanthemus Green.}

I832. C. pleurexanthemus Green, No. Amer. Jour. Geol., Vol. I, p. 560 , pl. 14, fig. Io.

I 847. C. pleurexanthemus Hall, Pal. N. Y., Vol. I, p. 242, pls. 65-66. I847. C. pleurexanthemus S. A. Miller, Cin. Quar. Jour. Sci., Vol. I, p. 132 .

This species is said to occur in Fayette County, but so far has not been observed by the writer. A specimen in the collection of the University of Iowa appears to belong to this species. It is said to come from the Maquoketa beds of an adjoining county, but the exact data are missing.

Ceraurus milleranus Miller and Gurley. Plate XVII, Figs. I-3. I894. C. milleranus Miller and Gurley, Bull. III, Ill. St. Mus. Nat. Hist., p. 8o, pl. 8, fig. ro.

Type specimen No. 6062 University of Chicago.

General outline of the carapace, exclusive of the spines, subovate, abruptly narrowed posteriorly; moderately convex, trilobation distinct.

Cephalon semielliptical, width nearly three times the length; dorsal furrows well marked. Glabella convex, narrower than the cheeks at the occipital ring, gradually widening anteriorly until its width about equals its length, abruptly bent downward at the frontal margin; anterior lobe constituting about one-third the length of the glabella; the three pairs of lateral furrows are short and about equidistant, forming three pairs of small convex lateral lobes; the two anterior pairs of furrows extend slightly forward, but the posterior pair is transverse for a part of its course and then bends abruptly backward until it meets the occipital furrow isolating the posterior lateral lobes. Occipital segment arched upward, higher than the anterior portion of the glabella, greatest height at the posterior margin, sloping gradually into the occipital furrow. This furrow is narrow and deep behind the posterior lateral glabella lobes but wider and shallow in its median portion. Cheeks convex with well-defined rounded marginal borders, posterior angle produced into spines, which point backward; eyes prominent, globular, placed near the center of the cheeks; the palpebral lobes bear a pit near the base on the side nearest to the dorsal furrows; the facial 
sutures originate on the lateral margins about in line with the occipital furrow, curve forward and inward to the palpebral lobes, which they traverse, thence pass forward with a sigmoid curve to the anterior margin of the cephalon.

Thorax composed of ten segments; axis convex, about the same width as the pleuræ; pleuræ flattened for one-third to one-half their width from the dorsal furrows, then bent downward and backward, tapering to a point; each pleural segment is ornamented with a prominent tubercle situated near the point where the pleuræ curve downward; an angular furrow originates on the anterior margin of each pleural segment at the dorsal furrow and crosses it obliquely, reaching the posterior margin behind the tubercle; dorsal furrows distinct, nearly parallel from the first to the eighth thoracic segment, then converging posteriorly.

Pygidium short, much narrower than the posterior segment of the thorax, consisting of three segments; the anterior segment bears a pair of stout spines, which extend posteriorly with the points somewhat converging; axis undefined.

Surface of the cephalon, within the marginal borders, covered with irregularly placed tubercles; on the cheeks the tubercles are somewhat farther apart and the interspaces are pitted; the marginal borders and genal spines are finely granulose; two or more conical tubercles are situated on the posterior borders of the cheeks; the entire thorax is finely granulose, as is also the pygidium, but the granulations are more conspicuous on the caudal spines.

Measurements of the type are as follows:

Length on median line......................

Length including caudal spines..................

Width at genal angles......................... 2 I.6 $\mathrm{mm}$.

Width at points of genal spines................

Length of cephalon including genal spines......... I I.5 mm.

Length of glabella...................... $8.0 \mathrm{~mm}$.

Width of posterior lobes of glabella ........... $6.0 \mathrm{~mm}$.

Width of anterior lobe of glabella................ $7.5 \mathrm{~mm}$.

Width of pygidium.................... $7.4 \mathrm{~mm}$.

Length of pygidium.....................

The above description is based on the type specimen from Cincinnati, Ohio, No. 6062 of the paleontological collection of the University of Chicago. The species is known to the writer from Fayette County by twelve more or less complete cephalons and two pygidia. These agree with the type except that in the type the genal spines are somewhat shorter, the tubercles on the posterior border are less conspicuous and 
the longitudinal curve of the glabella is somewhat more abrupt in front, making its anterior lobe appear shorter in dorsal view. This last feature may be due to distortion.

C. milleranus is distinguished from $C$. pleurexanthemus by its proportionally shorter cephalon, its less flaring genal spines, and by its eyes being globular and situated about equidistant from the dorsal furrows and from the posterior margin of the cephalon. The eyes of $C$. pleurexanthemus are conical and nearer the dorsal furrows. Further, the spines of the pyrgidium in $C$. milleranus converge at their points instearl of diverging as in $C$. pleurexanthemus.

Locality and horizon.-- Lower Maquoketa shales of Clermont and Elgin, Iowa.

Ceraurus elginensis sp. nov. Plate XTII, Figs. 4-5.

Type specimens Nos. P i6630A, i6630B, i 70,30 Ficld Museum.

Cephalon sublunate, width more than three times the length, anterior lateral margins arcuate, posterior margin transverse in the median portion, gently bent backward near the genal angles. Cilabella convex, clavate, less than half the width of the cheeks at its posterior margin but gradually widening anteriorly until its width nearly equals its length; anterior lobe constituting about one-fourth the entire length of the glabella; three pairs of lateral furrows rather short, well defined. defining three pairs of convex lateral lobes, diminishing in size posteriorly; the two anterior pairs of furrows are transverse, the posterior pair are transverse for part of their length, then bent backward until they join the occipital furrow, isolating the posterior lobes; occipital segment clevated at the posterior margin, sloping into the occipital furrow; occipital furrow shallow, concave in the median portion, narrower, deeper and bent backward behind the glabella lobes; dorsal furrows deep, angular, forming deep angular pits where they merge into the marginal furrows; cheeks large, convex, posterior angles produced into long, stout spines, flattened anteriorly and pointing almost directly hackward; palpebral lobes elongated, large for the genus, placed well forward, about midway between the dorsal furrows and the lateral margins but nearer the posterior margins than the dorsal furrows. Near the base of each lobe on the side towards the dorsal furrow is situated a decided pit; an indistinct furrow extends from this pit to the crest of the lobes; the ocular ridges extend from the anterior angle of the palpebral lohes to the pit in the dorsal furrows; the facial sutures originate on the lateral margins about in line with the posterior marginal furrow, curve forward and inward to the palpebral lobes which they traverse, then forward to the anterior margin, which they reach in 
front of the glabella; marginal borders prominent, defined by shallow furrows; the posterior furrows curve into the lateral furrows just within the genal angles; free cheeks small, less than one-third the size of the fixed cheeks. The surface of the glabella, with the exception of the occipital segment and the cheeks, is covered with more or less regularly distributed rounded tubercles; a larger, more conical tubercle is situated on each fixed cheek, just in front of the posterior furrow, at about onethird the distance from the dorsal furrow to the genal angle. A row of spine-like tubercles traverses the posterior marginal borders of the cheeks, and similar tubercles are distributed over the flattened portions of the genal spines, gradually diminishing in size posteriorly until they become obsolete.

Thorax not known.

Pygidium transversely sub-elliptical in outline, aside from the spines length less than half the width; composed of three segments, the extremities of the anterior segment produced into long, stout, flattened spines, which curve outward and backward; second and third segments much smaller; axis not well defined. The surface of the caudal spines is covered with sharp conical tubercles similar to those on the genal spines. The pygidium above described (P1. XVII, fig. 5) was not associated with the cephalons but came from the same horizon at Bloomfield. Its size and the form and ornamentation of the spines are such as might accompany these cephalons and no other cephalons have been observed to which this pygidium could well be referred.

\begin{tabular}{|c|c|c|}
\hline Measurements & P I6630A & P I6630B \\
\hline 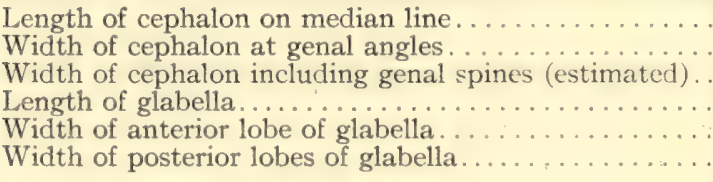 & $\begin{array}{r}13.7 \mathrm{~mm} . \\
38.5 \text { " } \\
40.0 \text { " } \\
\text { I3.0 " } \\
\text { II.5 " } \\
8.8 \text { " }\end{array}$ & $\begin{array}{l}12.3 \mathrm{~mm} \text {. } \\
36.3 \text { " } \\
38.0 " 1 \\
11.0 " \\
9.6 " \\
6.7 "\end{array}$ \\
\hline & \multicolumn{2}{|c|}{ P I7030 } \\
\hline $\begin{array}{l}\text { Width of pygidium. } \\
\text { Length of pygidium . . } \\
\text { Length of caudal spines (estimated) } \ldots \ldots \ldots \ldots\end{array}$ & \multicolumn{2}{|c|}{$\begin{array}{l}10.7 \mathrm{~mm} . \\
5.5 \\
20.0\end{array}$} \\
\hline
\end{tabular}

C. elginensis differs from all other species known to the writer in having extremely long genal spines with spinel-ike tubercles on their flattened portion. It is also distinguished from $C$. milleramus and $C$. pleurexanthemus by having the eves farther apart. It is most nearly related to $C$. dentatus Raymond and Barton, but the ocular ridges are not present in that species and the eves are not so far forward.

Locality and horizon.- The species is known to the writer from 
two cephalons from the top of the Lower Maquoketa beds at Elgin, Iowa, and a pygidium, which is referred with some doubt, from the same horizon at Bloomfield, Iowa.

\section{Genus ECCOPTOCHILE Corda 1847 .}

Body subovate in outline. Cephalon subsemicircular. Genal angles produced into spines. Glabella of uniform width rounded and full in front, glabella furrows short, transverse, posterior glabella lobe isolated or nearly so. Eyes holochroal. Pygidium short with three annulations on the axis, pleural lobes produced into three pairs of flat digitate extensions, obtusely rounded at their extremities, which do not extend beyond the marginal arc. (Clarke, Pal. Minn., Vol. III, pt. 2, p. 378.)

\section{Eccoptochile ? meekanus* S. A. Miller. Plate XVII, Figs. 6-9.}

I873. Ceraurus icarus Meek, Pal. Ohio, Vol. I, p. I62, pl. I4, figs. I Ia-c.

I889. Ceraurus meekanus S. A. M., N. Am. Geol. and Pal., p. 537. Type specimens Nos. 2409, 10837 University of Chicago.

Body subovate in outline, moderately convex, distinctly trilobed. Surface smooth to the naked eye but under a magnifier the cephalon appears finely granulose.

Cephalon subsemicircular, somewhat flattened anteriorly, genal angles produced into short spines, posterior margin nearly straight until it merges into the genal spines, where it is bent nearly at right angles (P1. XVII, fig. 8). Glabella subquadrate, rounded in front, length in front of the occipital furrow about equal to the width, depressed convex. Anterior lobe of the glabella transversely oval, about twice as wide as long, lateral lobes nearly transverse and about equal in size. Glabella furrows distinct, length about one-third the width of the glabella, anterior pair bent backward; middle pair nearly at right angles to the axis of the glabella; posterior pair similar to the middle pair for most of the length but having the inner ends abruptly bent backward until they meet the occipital furrow, isolating the posterior glabella lobes; occipital segment arched upward somewhat higher than the rest of the glabella, wider in the median portion, tapering towards the dorsal furrows; occipital furrow deep and narrow, arched forward. Dorsal furrows deep and narrow, diverging slightly at the posterior margin of the cephalon, thence passing to the front of the glabella, which they

*As this paper is going to press, the writer is informed that a new genus has been made by Barton of which this species is the genotype. 


\section{Field Museum of Natural History - Geology, Vol. IV.}

surround, leaving a narrow anterior border. In each furrow just in front of the anterior glabella furrow is a distinct pit. Cheeks large, sloping anteriorly and laterally from the eyes; posterior cheek furrows narrow; near the genal angles they meet the lateral furrows, which are wider and extend forward parallel to the margins until they meet the dorsal furrows; marginal borders somewhat concave on account of shallow marginal furrows, which originate on the genal spines. Eyes of moderate size, situated opposite the second glabella furrows, visual surface sublunate, palpebral lobes moderately prominent, approaching in height that of the glabella. The facial sutures originate a short distance in front of the genal angles, curve obliquely forward, then abruptly inward to the posterior angles of the eyes, follow the inner margin of the eyes and again forward with a broad curve, cutting the anterior margin of the cephalon in front of the glabella (P1. XVII, fig. 8.)

Thorax somewhat longer than wide, consisting of eleven segments, distinctly trilobed. Axis narrower than the pleuræ, regularly arched upward. Pleural lobes flattened for about one-third their width, thence abruptly curved to their lateral margins; each segment marked by a deep groove across the axis; another smaller groove originates on the anterior margin of each pleura near the dorsal furrows and crosses the pleura obliquely; on the anterior margin of each pleura, near the point where the pleura is bent downward, a still smaller groove defines a low oblong node which points forward, not upward. The segments are nearly transverse across the axis and about half the length of the pleuræ; their distal portions curve gently backward to the falcate extremities.

Pygidium small, transversely subelliptical, width more than twice the length, posterior curve much flattened. Axis small with three well defined annulations. Two shallow pits occur just back of the termination of the axis. Pleural lobes large, composed of three segments which are produced posteriorly into flattened spines. The anterior pair is the largest; carinate on top, strongly curved backward and obtusely rounded at the extremities; the other two pair decrease in size inward and are more pointed.

Remarks.- Of the specimens here figured and described, figs. 6 and 7 , are two views of an enrolled individual, complete with the exception of the genal spines, in the collection of Mr. A. G. Becker, from the Lower Maquoketa shale, Clermont; while figs. 8 and 9 (Mus. No. P I I I30) show specimens collected by the writer in the top of the Lower Maquoketa beds at Clermont. In fig. 8 the position of the facial suture and the angle formed by the posterior margin of the cephalon and the genal angles are well illustrated. In Meek's original figure this angle is shown as a 
curve, but the type specimen, now in the paleontological collection of the University of Chicago, agrees with the specimen here described.

Localities and horizons. - The type specimens were from the Richmond beds in Butler County, Ohio, and Richmond, Indiana. The specimens here described are from the Lower Maquoketa beds, Clermont, Iowa.

\section{Genus SPHÆROCORYPHE Angelin 1852.}

Cephalon convex, genal angles spined; glabella spheroidal anteriorly, lateral lobes obscure; eyes prominent; facial sutures cut the lateral and frontal margins. Thorax composed of 8-10 segments; axis narrower than the pleuræ; pleural segments terminate in short reflexed spines. Pygidium composed of three segments, the extremities of the anterior one produced into long spines. Type $S$. granulata. Range Ordovician, Europe and North America.

Spharocoryphe mapuoketensis sp. nov. Plate XV, Figs. i-4.

Type specimens Nos. P III52A, III52B, I6954 and I705I Field Museum.

Cephalon sublunate in outline, convex, distinctly trilobed; anterior margin truncated; posterior margin nearly transverse. Glabella very prominent, anterior lobe globular, produced beyond the anterior margin; comprising fully three-fourths the bulk of the glabella; a single pair of shallow, transverse, lateral furrows meet just behind the lateral lobe of the glabella and separate it from a pair of indistinct lateral lobes; occipital segment arched slightly forward, its posterior margin abruptly elevated, surface sloping into the furrow; occipital furrow shallow, not well-defined except at its extremities. Dorsal furrows well defined, much wider and deeper at the junctures with the occipital and glabella furrows, diverging somewhat in passing forward from the posterior margin of the cephalon until near the anterior margin where they abruptly converge until they meet forming the anterior marginal furrow; cheeks depressed convex, greatest elevation at the palpebral lobes which are situated about midway between the posterior and anterior margins and one-third the distance from the dorsal furrows to the genal angles; antero-lateral margins of the cheeks forming an elongate sigmoid curve; free cheeks triangular, small, less than onehalf the size of the fixed cheeks; eyes large, prominent, globular; the facial sutures originate on the lateral margins well in front of the genal angles, pass inward and slightly backward over the palpebral lobes, thence forward to the anterior margin; the genal angles merge into stout, recurved spines; the posterior marginal furrows are continuations 
of the occipital furrow but narrower and deeper; they terminate abruptly before the genal angles are reached; a deep elongate pit on each fixed cheek and a longer, shallower one on each free cheek represent the lateral marginal furrows.

Thorax not observed.

Pygidium small, sub-triangular in outline, aside from the spines; not distinctly trilobed, composed of three segments; the first of these has its extremities produced into long, diverging, slightly recurved spines; margin entire, with its ventral. surface forming a thick doublure.

Surface of the globular portion of the glabella pustulose; pustules rounded, larger near the transverse glabella furrow and gradually diminishing in size anteriorly; balance of cephalon smooth or finely granulose; surface of pygidium pustulose, pustules more prominent on the spines.

\begin{tabular}{|c|c|c|}
\hline Measurements of cephalon & $\begin{array}{l}\text { Holotype } \\
\text { P III52A }\end{array}$ & $\mathrm{P}$ III52B \\
\hline 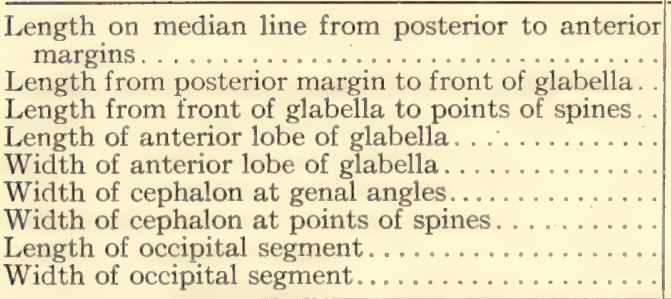 & $\begin{array}{r}4.6 \mathrm{~mm} \\
7.4 \mathrm{~mm} \\
\text { I3.0 } \mathrm{mm} \text {. } \\
5.0 \mathrm{~mm} \\
4.7 \mathrm{~mm} \\
10.2 \mathrm{~mm} \\
15.8 \mathrm{~mm} \\
2.3 \mathrm{~mm} \\
\text { 1. } \\
\text { I } \\
\text {. }\end{array}$ & $\begin{array}{l}10.4 \mathrm{~mm} \text {. } \\
7.7 \mathrm{~mm} \text {. } \\
7.5 \mathrm{~mm} \text {. } \\
14.6 \mathrm{~mm} \text {. } \\
3.3 \mathrm{~mm} \text {. } \\
1.2 \mathrm{~mm} \text {. }\end{array}$ \\
\hline Measurements of pygidium & $\mathrm{P}_{16954}$ & P $1705 \mathrm{I}$ \\
\hline 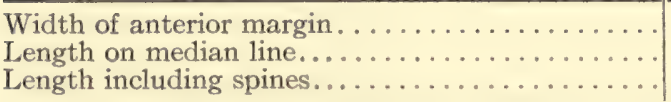 & $\begin{array}{l}3.4 \mathrm{~mm} \text {. } \\
1.5 \mathrm{~mm} \text {. } \\
4.2 \mathrm{~mm} \text {. }\end{array}$ & $\begin{array}{r}6.7 \mathrm{~mm} \text {. } \\
3.2 \mathrm{~mm} \text {. } \\
.0 .3 \mathrm{~mm} \text {. }\end{array}$ \\
\hline
\end{tabular}

This species is the most abundant trilobite in the shales of the Lower Maquoketa beds, but a great majority of the individuals are represented only by the globular portion of the glabella. They range in size from $2.5 \mathrm{~mm}$. to $7.5 \mathrm{~mm}$. in diameter. The writer was fortunate enough to obtain about twenty more or less complete cephalons and three pygidia. No thorax has been observed that can be referred to this species so that it is not certain that these pygidia belong to the cephalons, yet from their form and the conditions under which they were collected, there is little doubt that they belong to this species.

S. maquoketensis differs from all previously described species in possessing large pits in place of the lateral marginal furrows. It resembles S. granulata Angelin in the form of the marginal outline, but in $S$. maquoketensis the cephalon is longer in proportion to the width and the pustules on the glabella are finer. S. salteri Billings is from a similar horizon, but in $S$. salteri the width of the glabella at its posterior margin 
is three-fourths of its greatest width, and it has tubercles at the juncture of the occipital and dorsal furrows; in $S$. maquoketensis the glabella is twice as wide anteriorly as posteriorly and the tubercles are wanting.

Localities and horizons. - Abundant in the top layers and somewhat less so in the middle layers of the Lower Maquoketa shales of Clermont, Elgin, and Bloomfield, Iowa.

\section{Family PHACOPIDÆ, Salter.}

\section{Genus PTERYGOMETOPUS Schmidt i88ז.}

Cephalon obtusely angular in front. Glabella enlarging anteriorly, lateral furrows well defined. Eyes large, schizochroal. Posterior limb of the facial suture cuts the margin well in front of the genal angles, and the anterior limb crosses the lateral expansions of the frontal lobe of the glabella. Pygidium rounded, margin entire, without caudal spine. Range, Ordovician of Europe and North America.

\section{Pterygometopus Fredricki sp. nov. Plate XVIII, Figs. I-5.}

\section{Type specimen No. P I 7024 Field Museum.}

Test elongate-ovate in outline, trilobation distinct. Cephalon sublunate in outline, convex, anterior border rather thick and rounded, posterior margin concave, genal angles rounded. Glabella large, convex, greatest elevation and greatest width near the anterior margin, well defined by the dorsal furrows; anterior lobe large, transversely elliptical, rising abruptly from the anterior border; it comprises more than half of the glabella; anterior pair of lateral furrows originating at the anterior angles of the eyes, passing obliquely backward but not crossing the glabella; second pair of lateral furrows smaller than the first and directed obliquely forward forming a pair of triangular lateral lobes; the third pair of lateral furrows bifurcate, the anterior forks extending forward parallel to the second lateral furrows defining the quadrangular second lateral lobes, the posterior forks extending backward until they join the occipital furrow isolating the small, posterior, glabella lobes; occipital segment elevated at its posterior margin sloping to the occipital furrow; occipital furrow narrow, distinct. Dorsal furrows narrow and deep, nearly parallel from the posterior margin of the cephalon to the third, lateral glabella furrows, thence diverging to the antero-lateral margins. Cheeks slope regularly to the lateral margins; marginal borders wide at the genal angles narrowing in each direction, marginal furrows shallow on the lateral margins, deeper on the posterior margins; palpebral lobes large, prominent, but not equaling the glabella 
in height; marked by a distinct furrow just within and parallel to the borders of the eyes; eyes large, lunate, extending from the posterior cheek furrows to the anterior glabella furrows, eye facets arranged in vertical rows of five facets each; the facial sutures originate on the lateral margins in front of the genal angles, curve inward with a sigmoid curve to the posterior angles of the eyes, follow the inner margin of the eyes to their anterior angles and thence pass forward to the anterior margin of the cephalon.

Thorax distinctly trilobed, composed of eleven segments. Axis convex, occupying somewhat more than one-third the width of the thorax; the pleural segments extend outward from the dorsal furrows for a little more than one-third their length, from which point they bend backward and abruptly downward to the lateral margins; extremities rounded; a straight groove originates near the anterior edge of each of the pleural segments at the dorsal furrows, extends slightly backward and outward and becomes obsolete on the flattened surface of each segment. The dorsal furrows converge slightly to the ninth thoracic segment, then more rapidly to the pygidium.

Pygidium subsemicircular in outline, slightly produced posteriorly, strongly trilobed. Axis narrow, convex, margins slightly incurved, abruptly rounded posteriorly; there are ten sinuous annulations; dorsal furrows narrow and deep, entirely surrounding the axis; the pleural lobes, consisting of six to eight segments, each bearing a median groove, curve slightly upward in their anterior portion, then downward to the margins. The segments are defined by grooves which are distinct in the anterior portion of the pygidium but gradually become obsolete posteriorly. This feature is more noticeable in young specimens. Both segmentation and median grooves become obsolete a short distance from the margins, thus leaving a smooth, undefined, marginal border.

The surface of the thorax and pygidium appears smooth to the eye, but under a magnifier is finely punctate, without nodes or spines. The surface of the cephalon is pustulose, the pustules on the glabella being somewhat more prominent than on other parts.

The dimensions of the type specimen (Mus. No. P I7024) are as follows: Length, $24.2 \mathrm{~mm}$.; width at genal angles II.5 mm.; length of cephalon on median line $6.7 \mathrm{~mm}$.; length including genal angles $7.4 \mathrm{~mm}$.; length of thorax II. $5 \mathrm{~mm}$.; length of pygidium $6 \mathrm{~mm}$.; greatest width of pygidium $8.7 \mathrm{~mm}$. A detached pygidium (Mus. No. P I6923A) measures, length II.० mm.; greatest width I $4.6 \mathrm{~mm}$.; it has ten annulations in the axis and eight segments in each pleural lobe, the last two being visible only with a magnifier. This is the largest pygidium observed and appears to belong to an old individual. 
A small coiled specimen (Pl. XVIII, figs. $4^{-5}$ ) in the collection of Mr. A. G. Becker, found associated with typical specimens, is doubtfully referred to this species. It differs from the type in having a smooth instead of a pustulose glabella and the pygidium appears to be shorter in proportion to its width. Considering these characters in connection with its small size, it is probable that they only indicate the immaturity of the specimen. Its dimensions are: Length of cephalon $5 \mathrm{~mm}$.; length of thorax $10.4 \mathrm{~mm}$., length of pygidium $3.3 \mathrm{~mm}$.; width at genal angles $6.8 \mathrm{~mm}$.; width at anterior margin of pygidium $4.9 \mathrm{~mm}$.

$P$. fredricki is distinguished from $P$. larrabee $i$ by having five rows of eye facets instead of eight, by its more inflated anterior portion of the glabella, by its thicker and shorter anterior margin, by its shorter pygidium and fewer annulations on its axis, and by the anterior limbs of the facial suture being less divergent. So far as is known to the writer, the number of rows of eye facets has not previously been used as a specific character, but it seems to be a constant character in the thirty specimens of the two species which he has observed. Specimens of $P$. callicephalus from the Trenton of Ottawa, Canada, which appear to be typical, have eight rows of eye facets. $P$. fredricki appears to be related to $P$. callicephalus, but aside from the eye facets, the glabella is more inflated anteriorly and the anterior margin is smaller and less angular in $P$. fredricki.

The specific name is given in honor of Dr. Fredrick Becker, who was one of the first collectors of fossils in Fayette County and who gave the writer much valuable information as to localities.

Localities and horizon.- The type is from the top of the Lower Maquoketa beds at Bloomfield, Iowa. The species has been observed in beds somewhat lower down at Clermont and at Postville Junction, Iowa.

\section{Pterygometopus larrabeeI sp. nov. Plate XVIII, Figs. 6-8.}

Type specimen No. P I I 256 Field Museum.

Cephalon sublunate in outline, anterior margin produced into a thin subangular lip, genal angles well back of the occipital ring, rounded. Glabella large, depressed, convex, about twice as wide in front as at the occipital ring, anterior lobe transversely elliptical sloping gently towards the front, comprising fully half the glabella; anterior pair of glabella furrows originating at the anterior angles of the eyes and passing obliquely backward but not meeting at the median line of the glabella; second pair of glabella furrows shorter and shallower than the first, directed obliquely forward; third pair of glabella furrows directed towards the axis of the glabella for a short distance, then bifurcating, 
the posterior forks bending abruptly backward and joining the occipital furrow leaving the small posterior lobes entirely detached; the anterior and larger forks bending obliquely forward defining the third glabella lobes; occipital segment wide, slightly rounded, of about uniform width until near the dorsal furrows where it is abruptly constricted; occipital furrow shallow but distinct. Dorsal furrows narrow and deep, nearly parallel from the posterior margin of the cephalon to the posterior glabella furrows, thence diverging in a regular curve to the anterior angle of the eyes where they become obsolete. Palpebral lobes large, prominent, exceeding the glabella in height, marked with a distinct furrow just within and parallel to the border of the eye; eyes large, lunate, extending from the posterior cheek furrows to the anterior furrows of the glabella; eye facets arranged in vertical rows of eight facets each; the cheeks curve regularly to the lateral margins, marginal borders rather wide on their lateral margins, narrow on their posterior margins, marginal furrows shallow on their lateral margins, narrower and deeper on the posterior margins. The facial sutures originate on the lateral margins well in front of the genal angles, curve inward and backward to the posterior angles of the eyes, follow the inner margin of the eyes to their anterior angles and thence curve outward to the margin of the cephalon, almost in line with the anterior furrows of the glabella. Surface of the glabella distinctly pustulose; that of the palpebral lobes, cheeks, occipital ring and anterior projection finely granulose.

Thorax not known.

Pygidium subtriangular, somewhat rounded posteriorly, distinctly trilobed. Axis narrow, convex, margin slightly incurved, abruptly rounded posteriorly; there are thirteen sinuous annulations; the dorsal furrows entirely surround the axis; the pleural lobes, marked by seven or eight segments each bearing a median groove for part of its length, curve regularly to the lateral margins; both segmentation and grooves become obsolete a short distance from the margin, leaving a plain, undefined marginal border. The entire surface of the pygidium is finely punctate.

Measurements.- Type specimen (Mus. No. P II256). Length of cephalon on median line $9.5 \mathrm{~mm}$., length including genal angles ro $\mathrm{mm}$., width of cephalon I $4.5 \mathrm{~mm}$.; length of pygidium $9.2 \mathrm{~mm}$., width 10.6 $\mathrm{mm}$., width of axis on anterior margin of pygidium $3 \mathrm{~mm}$., length of axis $7 \mathrm{~mm}$. Another complete cephalon gave the following: Length on median line II mm., length including genal angles $12.5 \mathrm{~mm}$., width I $7.5 \mathrm{~mm}$.

Remarks. - The above description is based on the type specimen (Mus. No. P I I256) consisting of a complete cephalon and a nearly com- 
plete pygidium. In general form this species resembles $P$. callicephalus but differs from it in the following characters: In $P$. larrabeei the cephalon is longer in proportion to the widtt abruptly to the lateral margins; the glabella is less inflated anteriorly; the pygidium is longer and has more annulations and segments; the pustulose surface occurs only on the glabella; the surfaces of the palpebral lobes, occipital ring and checks are punctate. The pygidium of $P$. larrabeei appears to be midway between $P$. callicephalus and $P$. intermedius in form. The specific name is given in memory of the late Ex-Governor William Larrabee on whose property some of the specimens were collected.

Locality and horizon.- More or less complete cephalons and pygidia are comparatively abundant in the Lower Maquoketa beds at Clermont. Elgin, and Bloomfield. The type specimen came from Clermont.

\section{ACKNOWLEDGMENTS}

The generic descriptions used in this paper have been derived from a number of sources. Where practicable a copy of the original description of the genus has been given; in other cases the best descriptions available have been used. In nearly all cases the descriptions have been rewritten, but where copied due credit has been given.

The writer is under obligations to Mr. A. G. Becker of Clermont for the loan of specimens and assistance given while in the ficld. $\mathrm{Mr}$. Becker not only placed his private collection at the disposal of the writer, but spent much time with him in actual collecting and gave valuable information as to localities to be visited. Also to Prof. George F. Kay for the loan of specimens from the paleontological collections of the State University of Iowa, and to Prof. Stuart Weller of the University of Chicago for the loan of type specimens and publications which materially aided in the preparation of this paper, grateful acknowledgments are given. 



$$
8
$$


EXPLANATION OF PLATE XIII

Isotrelus IOWENsis, Owen, page 48.

Fig. 1. View of the inner surface of the test, showing position of the facial suture. Mus. No. P I1241. X 1 .

Fig. 2. Ventral view of a cephalon in the paleontological collection of the State University of Iowa, showing form and position of the hypostoma and sutures. $X \% / 7$. 

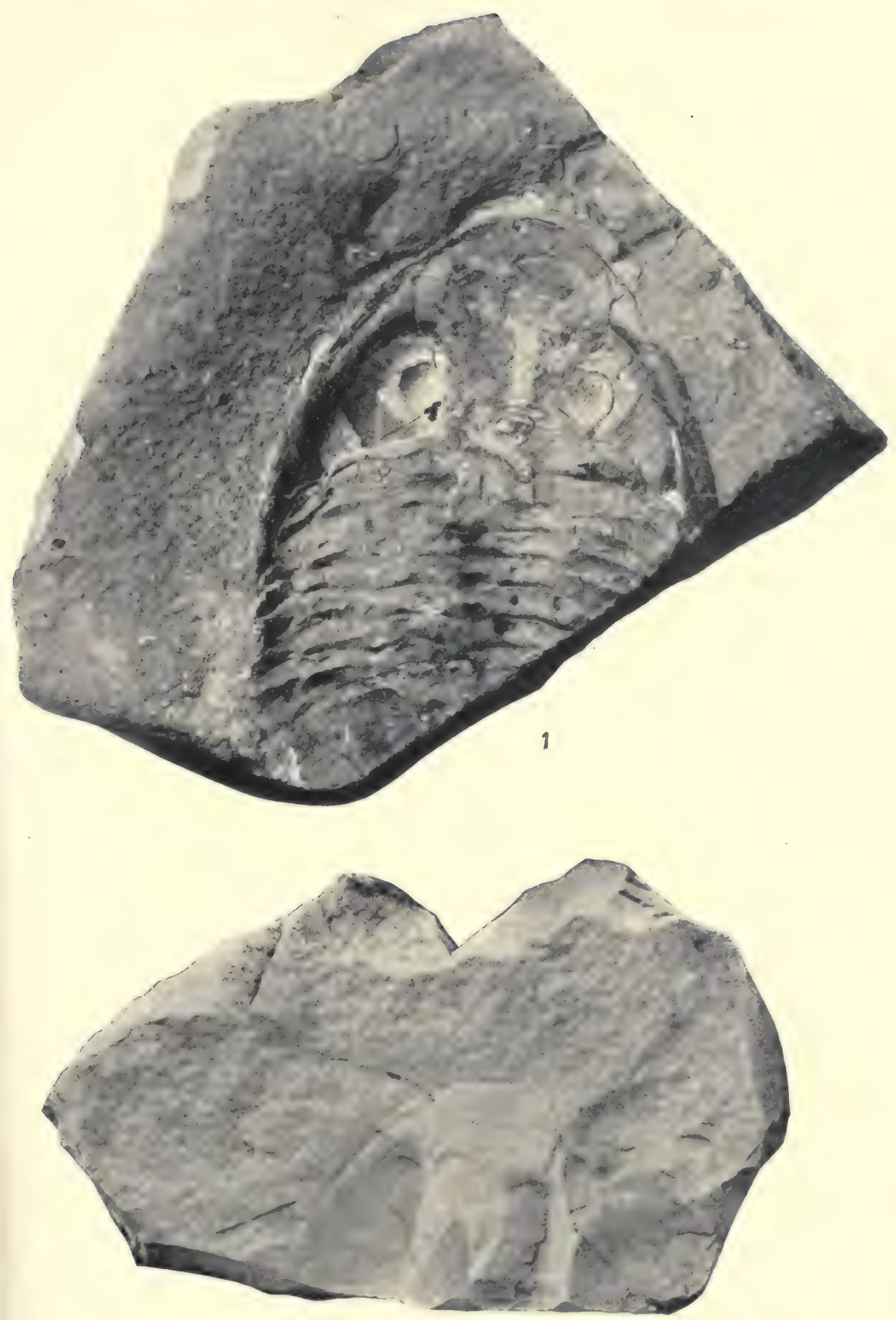
LIBRARY

UNIVERSIIY OF ILLINOIS

UnGANi 

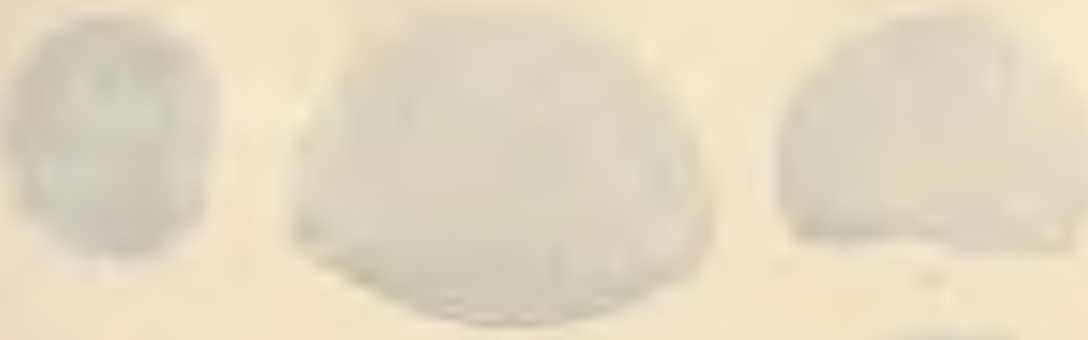

(2)

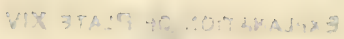

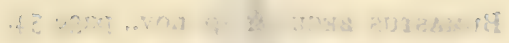

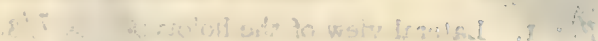

.

$$
\text { (n) }
$$$$
\text { . }
$$
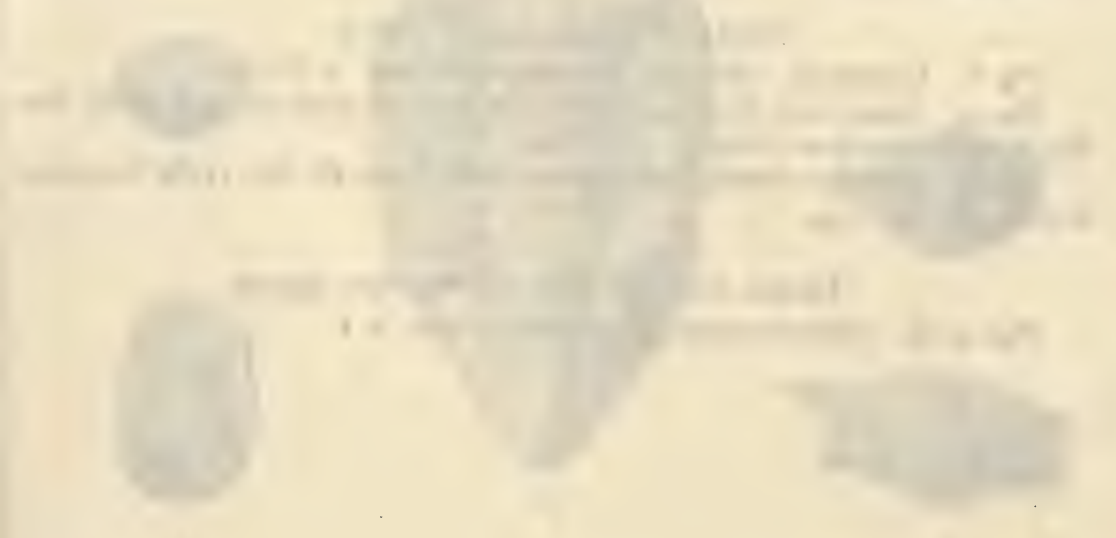

(1)
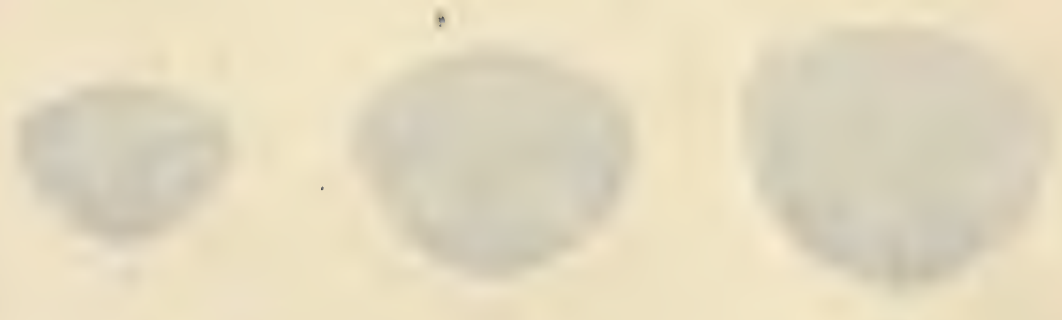
BuMastus BECKERT sp. nov., page 54 .

Fig. r. Lateral view of the holotype. $\times 7 / 8$.

Figs. 2, 3. Dorsal and lateral views of the paratype in the paleontological collections of the State University of Iowa. $\times 4 / 3$.

Fig. 4. Dorsal view of the paratype. Mus. No. P I6708. $\times 7 / 8$.

\section{Megalaspis beckeri sp. nov., page 50.}

Fig. 5. Dorsal view of the type specimen. $\times \mathrm{I}_{4} / \mathrm{IS}_{5}$

Thaleops ovata Conrad, page 56.

Fig. 6. Cranidium. Mus. No. P II259, Clermont. $X^{13 / 14}$.

Fig. 7. Dorsal view of a nearly complete specimen from Mineral Point, Wis. No. 6901 University of Chicago. $X^{13 / 14}$.

Fig. 8. Cephalon showing cheek spines, from Dixon, Ill., No. 12584 University of Chicago. $\times x^{13 / 14}$.

NiLeus Vigilans Meek and Worthen, page 52.

Figs. 9-15. Series illustrating variations in size. $\times \mathbf{r}$. 
FIELD MUSEUM OF NATURAL HISTORY.
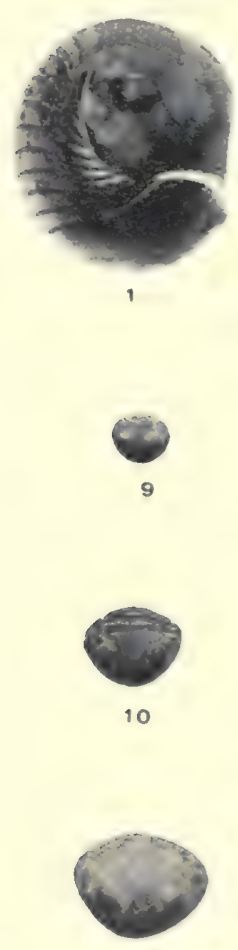

11

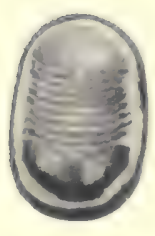

12

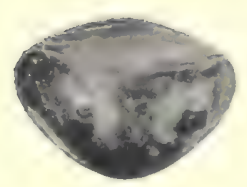

13

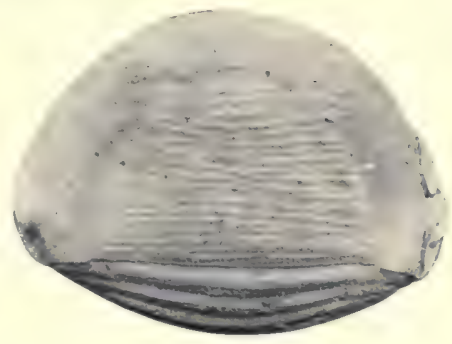

2

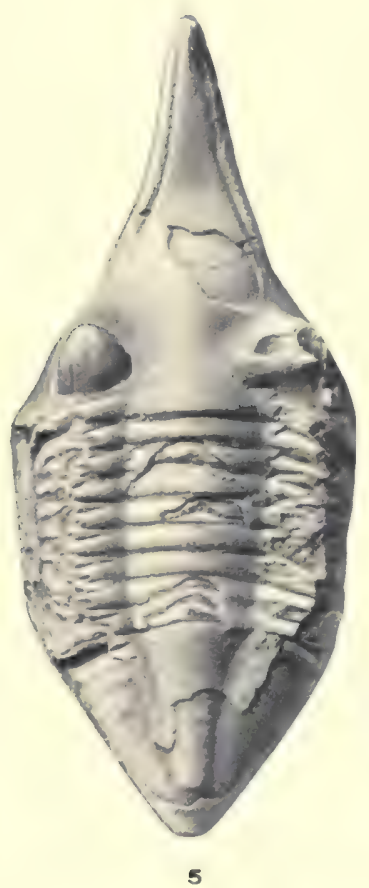

5

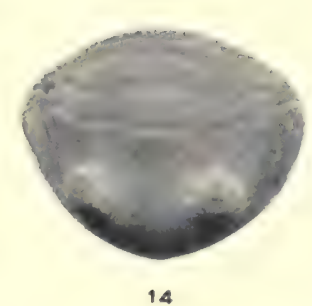

GEOLOGY, VOL. IV, PL. XIV

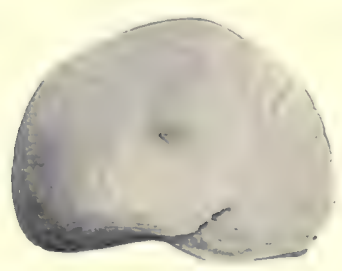

3
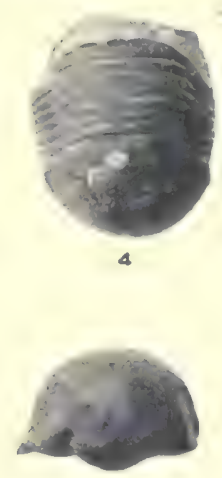

6
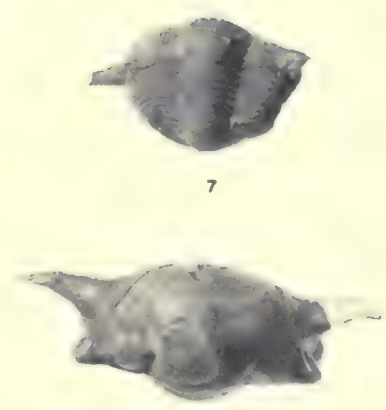

8

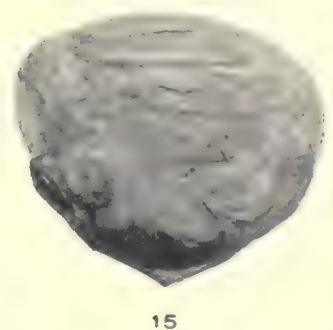


LIBRARY

UNIVERSITY OF ILLINOIS

URGANA 

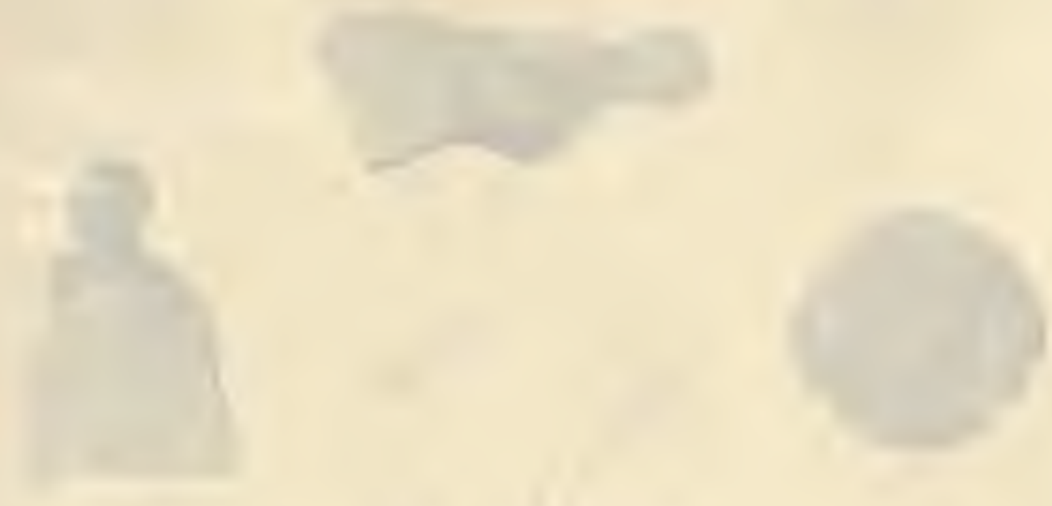

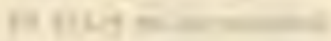

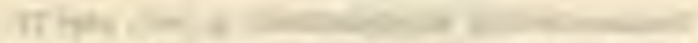

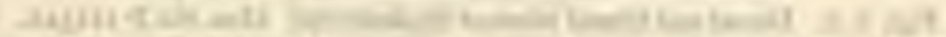

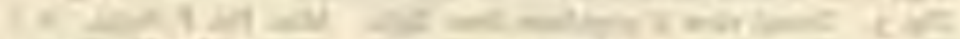

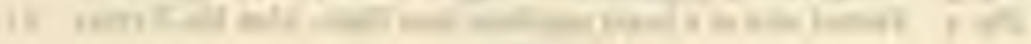

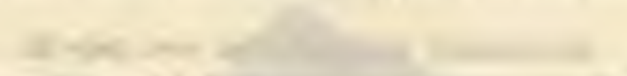

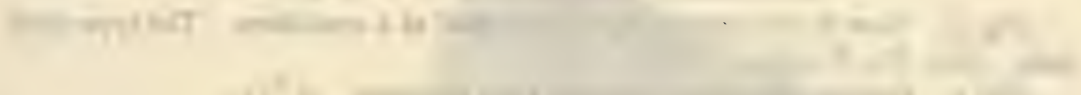

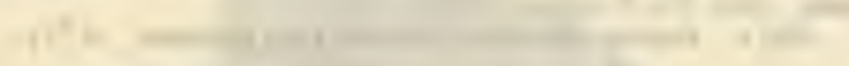

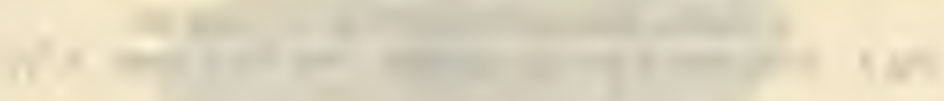




\section{EXPLANATION OF PLATE XV}

SPHAEROCORYPHE MAQUOKETENSIS sp. nov., page 77.

Figs. I, 2. Dorsal and lateral views of the holotype. Mus. No. P III52A. $\times 9 / 5$.

Fig. 3. Dorsal view of pygidium from Elgin. Mus. No. P x6954. $\times 1$.

Fig. 4. Ventral view of a larger pygidium from Elgin. Mus. No. P r 7051. Xr.

\section{AMpHILICHAS RHINOCERos sp. nov., page 58.}

Fig. 5. View of the inner surface of the shell of a cranidium. The type specimen. Mus. No. P III81. $\times 6 / 7$.

Fig. 6. Outline restoration from the type specimen. $\times 6 / 7$.

\section{AMPHILICHAS CLERMONTENSIS sp. nov., page 59.}

Fig. 7. Dorsal view of the type specimen. Mus. No. P I1257. $\times 6 / 7$. 

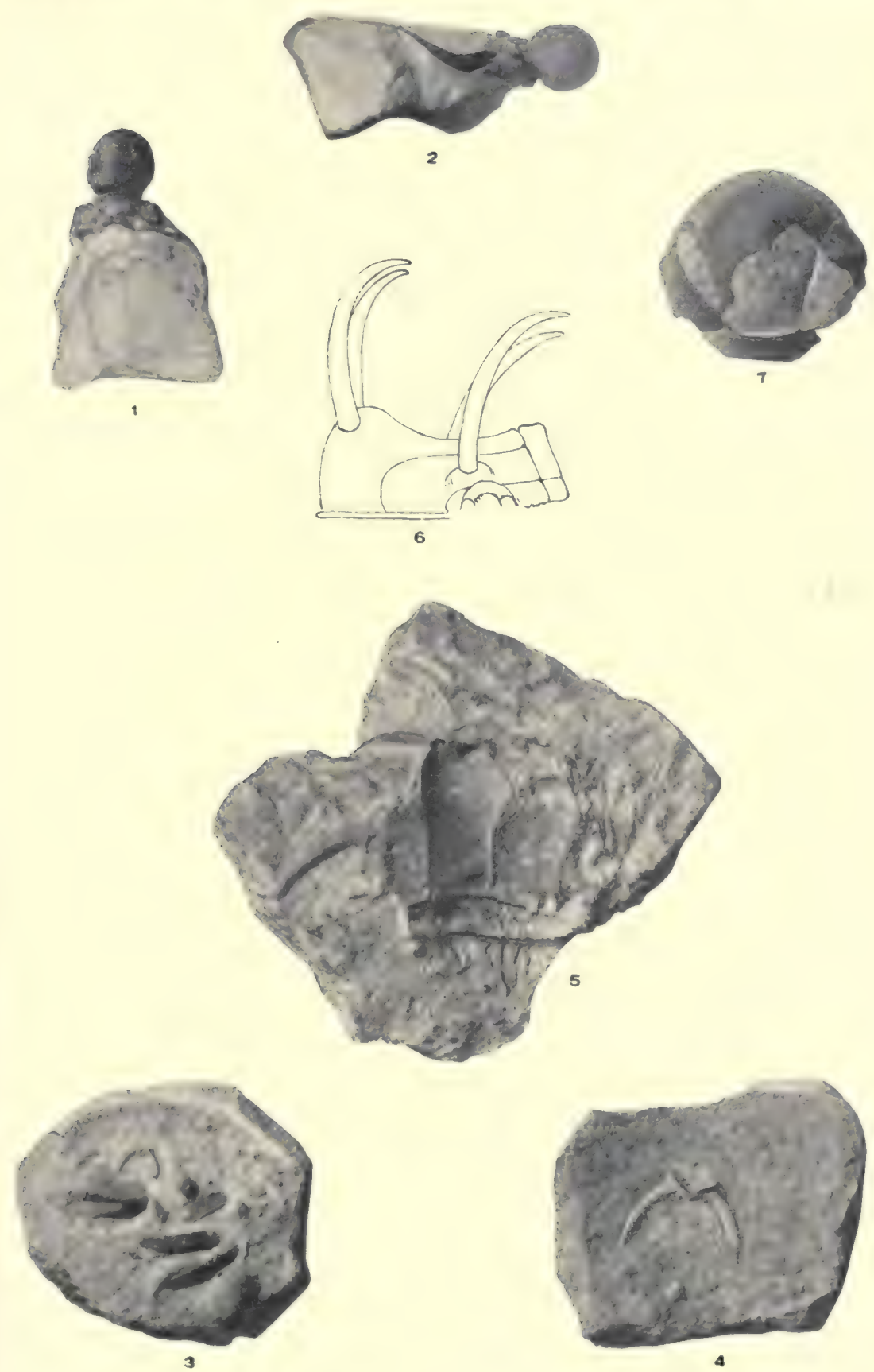
LIBRARY

UNIVERSITY OF ILLINOIS

URBANA 

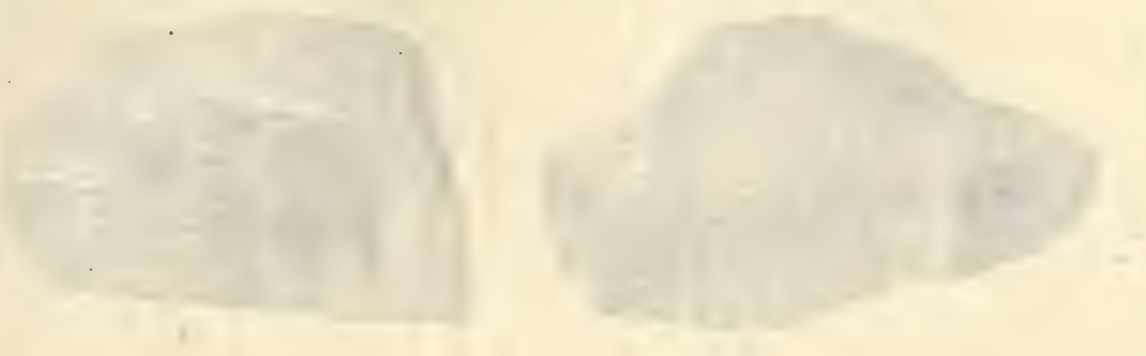

\section{(2)

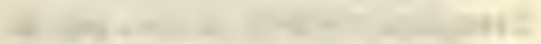

ax

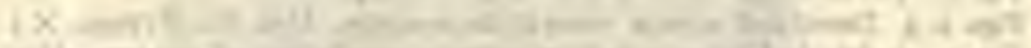

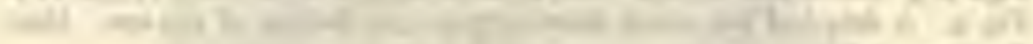

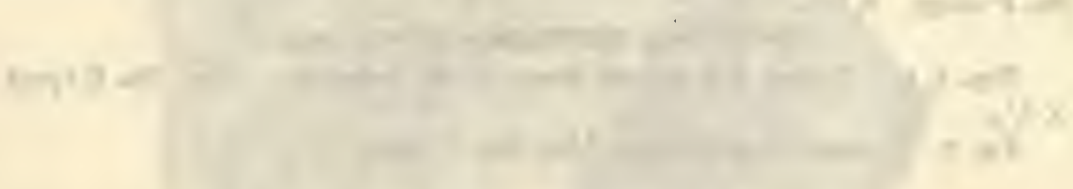

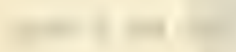

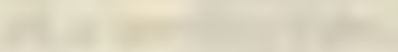

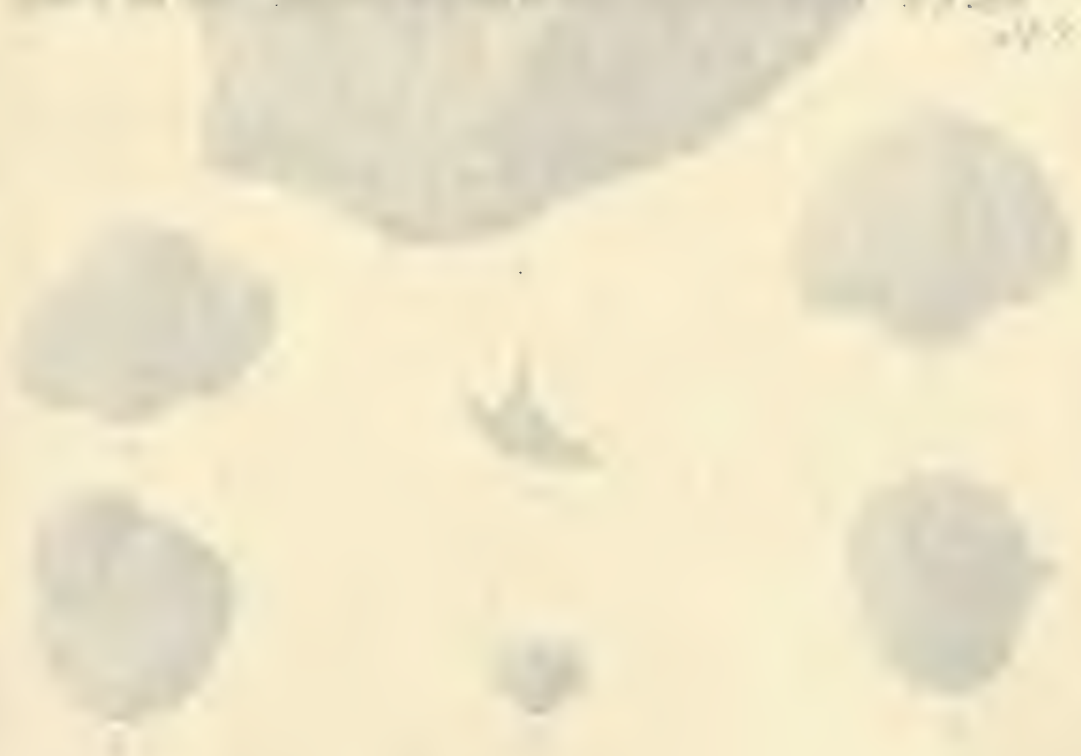




\section{ExPLANATION OF PLATE XVI}

\section{Cybeloides rowensis sp. nov., page 64 .}

Fig. 1. The holotype. Mus. No. P 16631. $\times 5 / 4$.

Figs. 2, 3. Dorsal and anterior views of the paratype. Mus. No. P I7039. $X I$. Fig. 4. A detached free cheek showing form and position of the eye. Mus. No. P 16633. $\times 5 / 4$.

ENCRINURUS PERNODOSUs sp. nov., page 6r.

Figs. 5, 6. Dorsal and lateral views of the holotype. Mus. No. $P_{17038 .}$ $\times 3 / 2$.

Fig. 7. A detached pygidium. Mus. No. P I6930. X I.

Calymene fayetrensis sp. nov., page 67.

Figs. 8, 9. Dorsal and lateral views of the type specimen. Mus. No. P 16755 . $\times 3 / 2$. 


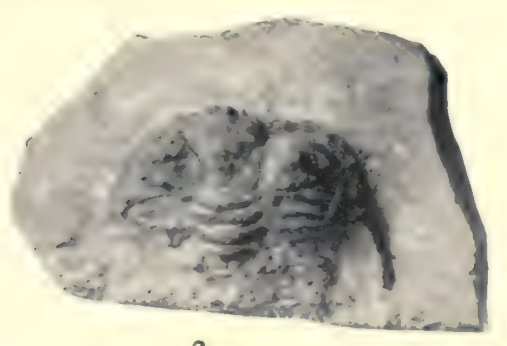

2

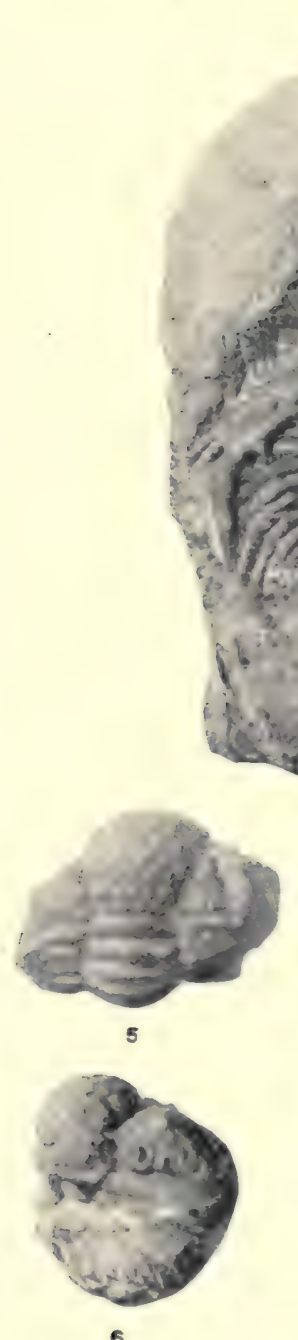

6

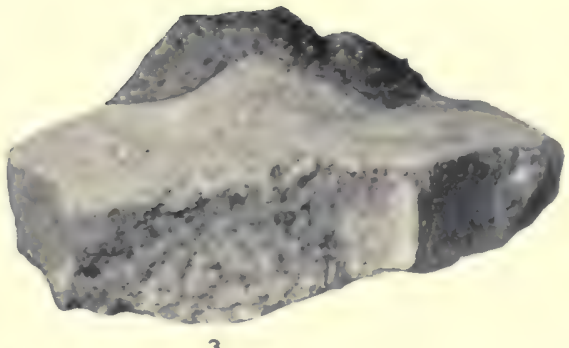

3 
LIBRARY

UNIVERSITY OF ILLINOIS

URBANA 

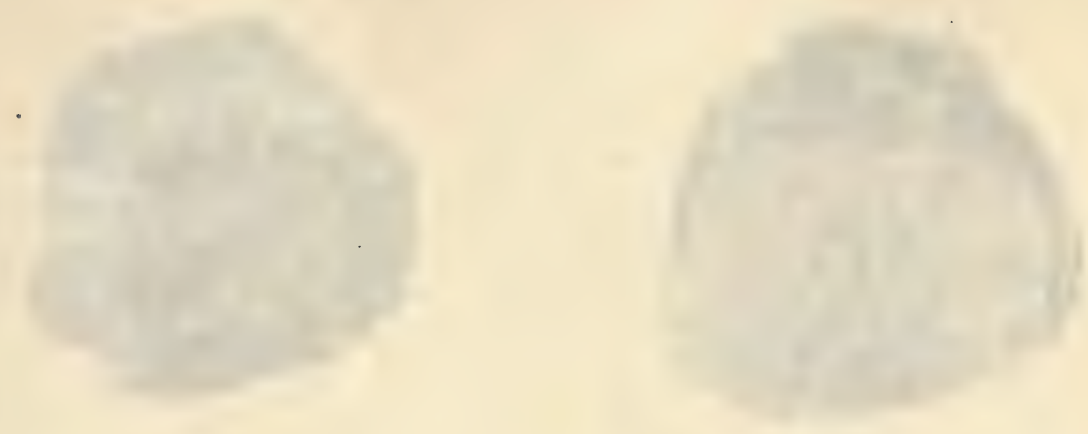

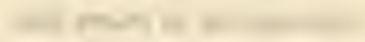
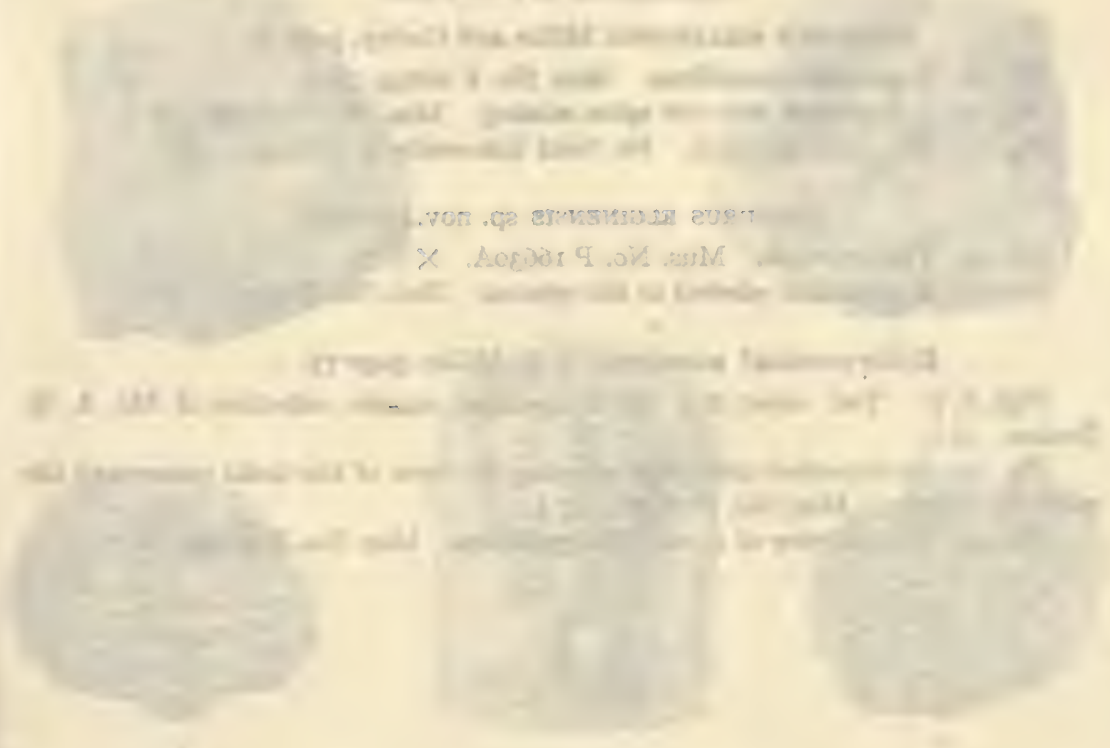
EXPLANATION OF PLATE XVII

Ceraurus milleranus Miller and Gurley, page 71 .

Fig. I. A complete cranidium. Mus. No. P 16853. X I.

Fig. 2. A pygidium with one spine missing. Mus. No. P 16925. X I.

Fig. 3. The type specimen. No. 6062 University of Chicago. $\times 1$.

Ceraurus elginensis sp. nov., page 73.

Fig. 4. The holotype. Mus. No. P I6630A. $\times 1$.

Fig. 5. A pygidium referred to this species. Mus. No. P I7030. X I.

Eccoptochile? meekanus S. A. Miller, page 75.

Figs. 6, 7. Two views of a coiled specimen in the collection of Mr. A. G. Becker. $\times x$.

Fig. 8. An imperfect cranidium showing the form of the facial suture and the posterior margin. Mus. No. P III50. $\times$ I.

Fig. 9. Ventral view of a complete pygidium. Mus. No. P IIr50. X I. 

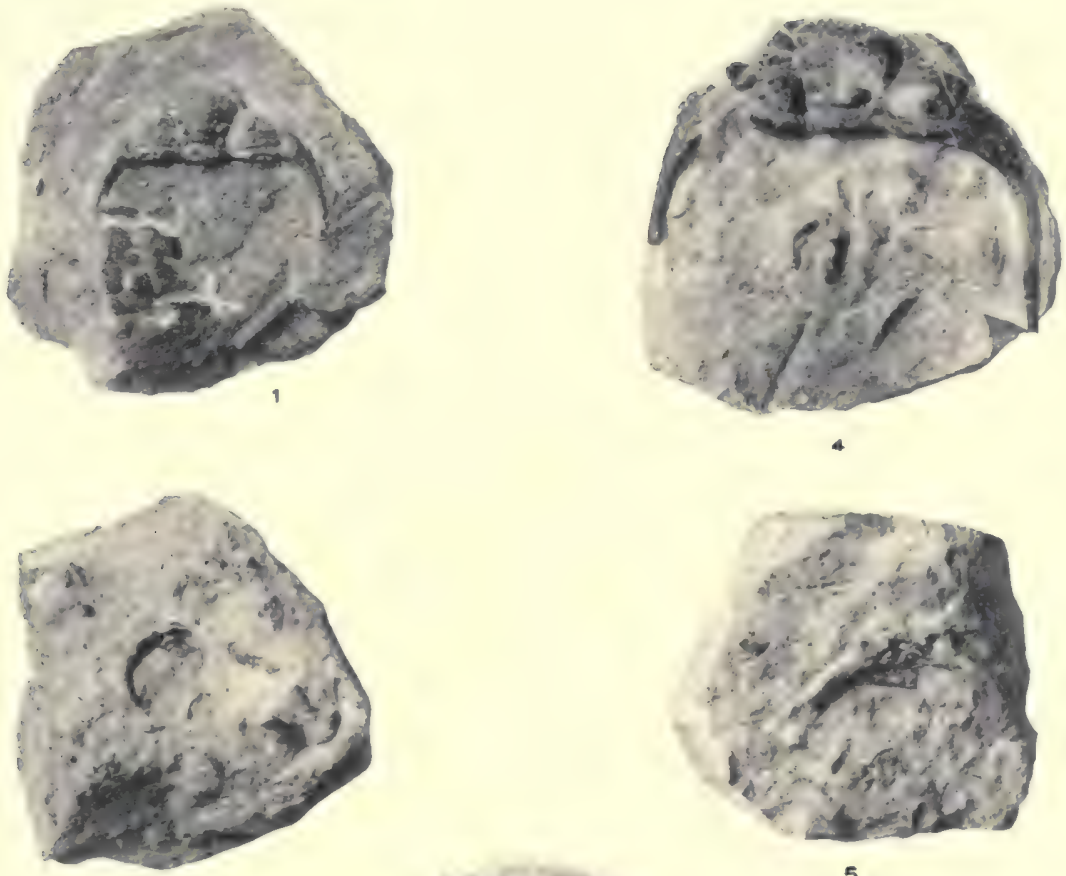

2

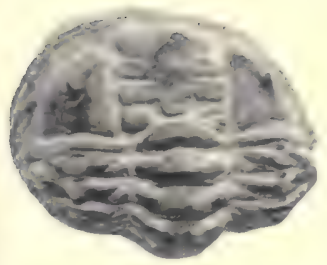

6

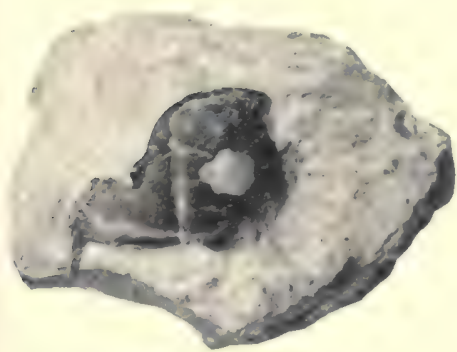

8

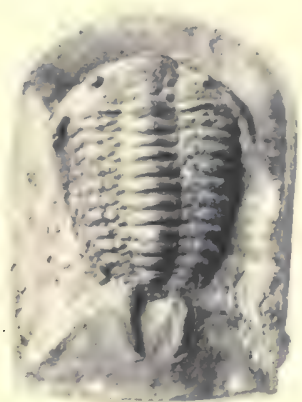

3
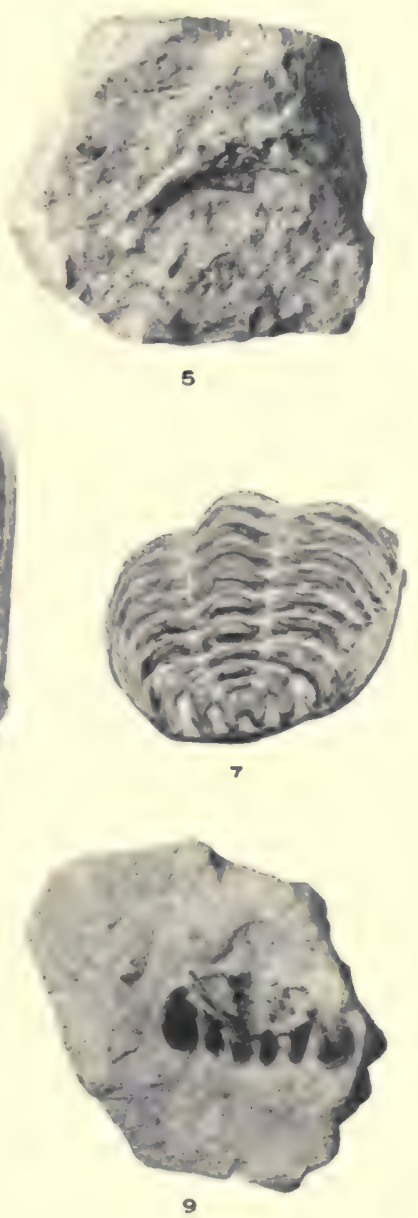
LIBRARY

UNIVERSITY OF ILLINOIS

URBANA 

Explanation Of PLATE XVIII

PTERYGometopus FREDRICKI sp. nov., page 79.

Fig. x. The type specimen. Mus. No. P I7024. $\times 3 / 2$.

Fig. 2. Dorsal view of the cephalon of the above. $\times 3 / 2$.

Fig. 3. Outline drawing of a lateral view of the same showing the form of the glabella. $\times 3 / 2$.

Figs. 4, 5. Dorsal and lateral views of a young specimen referred to this species, in the collection of Mr. A. G. Becker. $\times 3$.

Pterygometopus larRabeei sp. nov., page $8 \mathrm{I}$.

Fig. 6. The holotype. Mus. No. P I1256. $\times 5 / 4$.

Fig. 7. Outline drawing of a lateral view of the same showing form of the glabella. $\times 5 / 4$.

Fig. 8. Pygidium associated with the holotype. $\times 5 / 4$.

Calymene gracilis sp. nov., page 69.

Fig. 9. The type specimen. Mus. No. P 17065. $\times 5 / 4$. 


\section{FIELD MUSEUM OF NATURAL HISTORY.}

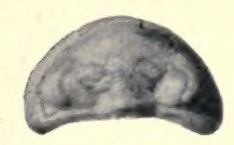

2

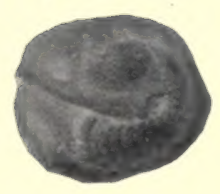

4

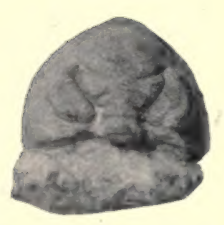

6
GEOLOGY, VOL. IV, PL. XVIII

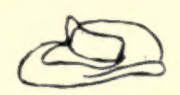

3

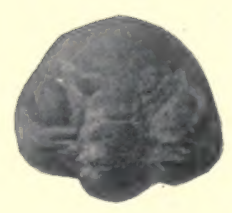

5
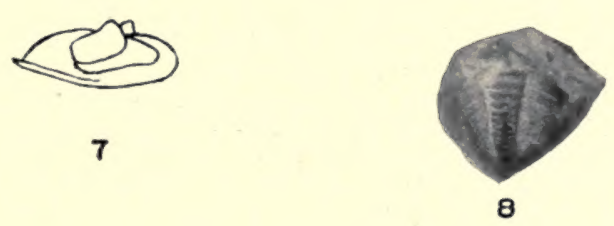

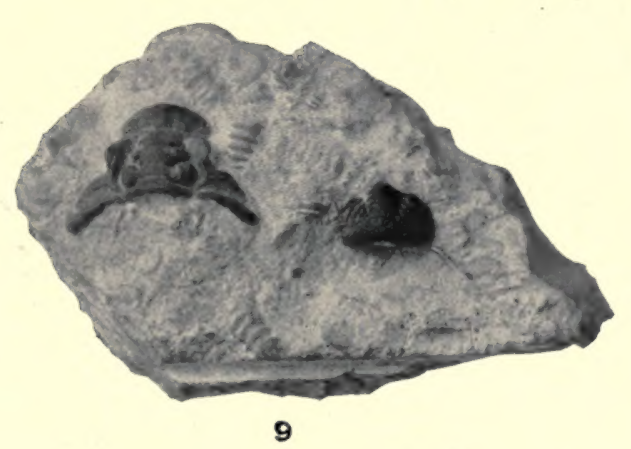




